\title{
Using Lidar Elevation Data to Develop a Topobathymetric Digital Elevation Model for Sub-Grid Inundation Modeling at Langley Research Center
}

Jon Derek Loftis

VIMS

Harry V. Wang

Virginia Institute of Marine Science

RJ DeYoung

WB Ball

Follow this and additional works at: https://scholarworks.wm.edu/vimsarticles

Part of the Aquaculture and Fisheries Commons

\section{Recommended Citation}

Loftis, Jon Derek; Wang, Harry V.; DeYoung, RJ; and Ball, WB, "Using Lidar Elevation Data to Develop a Topobathymetric Digital Elevation Model for Sub-Grid Inundation Modeling at Langley Research Center" (2016). VIMS Articles. 782.

https://scholarworks.wm.edu/vimsarticles/782

This Article is brought to you for free and open access by the Virginia Institute of Marine Science at W\&M ScholarWorks. It has been accepted for inclusion in VIMS Articles by an authorized administrator of W\&M ScholarWorks. For more information, please contact scholarworks@wm.edu. 


\title{
Using Lidar Elevation Data to Develop a Topobathymetric Digital Elevation Model for Sub-Grid Inundation Modeling at Langley Research Center
}

\author{
Jon Derek Loftis ${ }^{\dagger}$, Harry V. Wang ${ }^{\dagger}$, Russell J. DeYoung ${ }^{\ddagger}$, and William B. Ball ${ }^{*}$ \\ ${ }^{\dagger}$ Department of Physical Sciences \\ Virginia Institute of Marine Science \\ NASA Langley Research Center \\ Hampton, VA 23681, U.S.A. \\ College of William and Mary
}

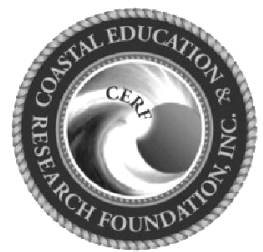

Gloucester Point, VA 23062, U.S.A.

www.cerf-jcr.org

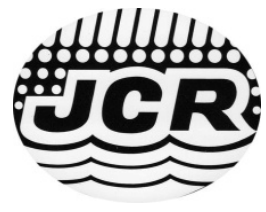

www.JCRonline.org

\begin{abstract}
Loftis, J.D.; Wang, H.V.; DeYoung, R.J., and Ball, W.B., 2016. Using lidar elevation data to develop a topobathymetric digital elevation model for sub-grid inundation modeling at Langley Research Center. In: Brock, J.C.; Gesch, D.B.; Parrish, C.E.; Rogers, J.N., and Wright, C.W. (eds.), Advances in Topobathymetric Mapping, Models, and Applications. Journal of Coastal Research, Special Issue, No. 76, pp. 134-148. Coconut Creek (Florida), ISSN 0749-0208.

Technological progression in light detection and ranging permits the production of highly detailed digital elevation models, which are useful in sub-grid hydrodynamic modeling applications. Sub-grid modeling technology is capable of incorporating these high-resolution lidar-derived elevation measurements into the conventional hydrodynamic modeling framework to resolve detailed topographic features for inclusion in a hydrological transport model for runoff simulations. The horizontal resolution and vertical accuracy of the digital elevation model is augmented via inclusion of these lidar elevation values on a nested 5-m sub-grid within each coarse computational grid cell. This aids in resolving ditches and overland drainage infrastructure at Langley Research Center to calculate runoff induced by the heavy precipitation often accompanied with tropical storm systems, such as Hurricane Irene (2011) and Hurricane Isabel (2003). Temporal comparisons of model results with a NASA tide gauge during Hurricane Irene yielded a good $\mathrm{R}^{2}$ correlation of 0.97 , and root mean squared error statistic of $0.079 \mathrm{~m}$. A rigorous point-to-point comparison between model results and wrack line observations collected at several sites after Hurricane Irene revealed that when soil infiltration was not accounted for in the model, the mean difference between modeled and observed maximum water levels was approximately $10 \%$. This difference was reduced to $2-5 \%$ when infiltration was considered in the model formulation, ultimately resulting in the sub-grid model more accurately predicting the horizontal maximum inundation extents within $1.0-8.5 \mathrm{~m}$ of flood sites surveyed. Finally, sea-level rise scenarios using Hurricane Isabel as a base case revealed future storm-induced inundation could extend $0.5-2.5 \mathrm{~km}$ inland corresponding to increases in mean sea level of $37.5-150 \mathrm{~cm}$.
\end{abstract}

ADDITIONAL INDEX WORDS: Flood modeling, storm surge, sea-level rise, Hurricane Irene, Hurricane Isabel, tidewater, Virginia.

\section{INTRODUCTION}

The central U.S. East Coast is characterized by a low coastal slope, a high concentration of salt marshes, and higher than average rate of relative sea-level rise (Boon, 2004; Shen and Gong, 2009). Each of these factors combine to effectively raise the flood susceptibility of the U.S. East Coast to have over $50 \%$ of its length categorized within the "very high" or "high" vulnerability range regarding inundation risk (Kleinosky, Yarnal, and Fisher, 2007). Inundation instigated by hurricane storm surge and storm systems along the U.S. East Coast is a substantial threat to residential properties, community infrastructure, and human life. During and after the storm, compounding with heavy precipitation and upland drainage, inundation can be caused by the combination of storm surge and river-induced inland flooding in various locations throughout the coastal plain (Gong et al., 2009; Loftis, Wang, and DeYoung,

DOI: 10.2112/SI76-012 received 31 August 2014; accepted in revision 7 August 2015.

*Corresponding author: jdloftis@vims.edu

${ }^{\circ}$ Coastal Education and Research Foundation, Inc. 2016
2013; Wang et al., 2005). This threat requires the use of highresolution inundation modeling to periodically assess the inundation risk in the coastal plain for a suite of potential flooding scenarios including storm surge and precipitation-based flooding. This is especially relevant not only for current flood mitigation strategies but also for new construction projects underway at National Aeronautics and Space Administration (NASA) Langley Research Center and Langley Air Force Base in Hampton, Virginia.

NASA Langley Research Center is precariously located in one of the most susceptible regions of the United States to the effects of sea-level rise (Figure 1). NASA Langley Research Center is surrounded by the Back River, a shallow estuarine inlet of the Chesapeake Bay, the largest estuary in the United States (Loftis, Wang, and DeYoung, 2013; Shen et al., 2006). The tidewater region of Virginia is adjacent to the banks of the Chesapeake Bay and its tributaries, and being within the coastal plain causes the research facility to be exposed to the inherent flood risks of hurricane storm surges compounded with heavy precipitation in a region characterized by an annually high water table (Virginia Institute of Marine Science, 2013). Stationed on 


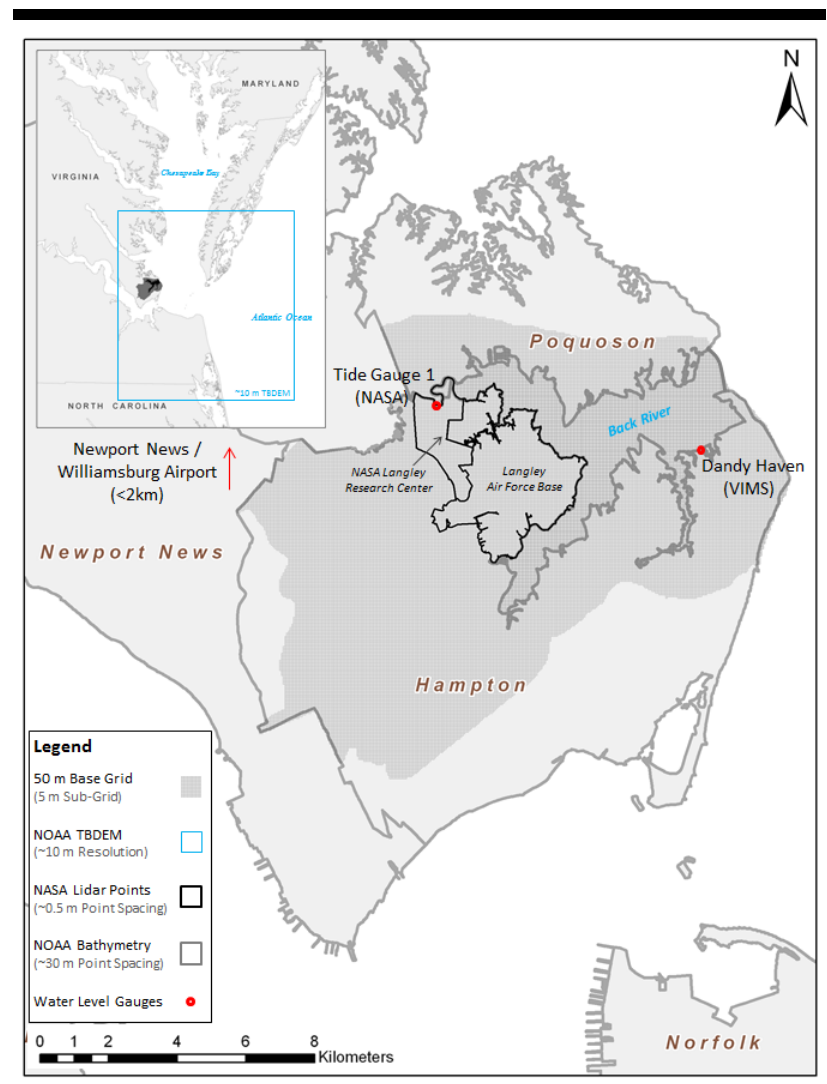

Figure 1. Study area showing 50-m resolution model grid (shaded dark gray) aligned with the Back River watershed showing the location of relevant data sources noted in the inset and legend.

$800+$ acres, with another 20 acres of research space allocated on Langley Air Force Base, NASA Langley Research Center represents a sizable asset to protect. Previously, the Chesapeake Inundation Prediction System has been developed and has demonstrated to provide a capability to forecast large-scale storm surge and land area inundated in the Chesapeake Bay (Cho et al., 2012; Stamey et al., 2007). The results presented in this study will demonstrate that sub-grid modeling technology can incorporate high density lidar elevation measurements provided by NASA Langley Research Center to resolve detailed drainage features for effective use as a hydrological transport model for runoff simulations within NASA Langley Research Center and Langley Air Force Base.

Sub-grid modeling technology has recently demonstrated the capability to incorporate fine-scale features (within 1-5 m) into a sub-grid contained within a coarse computational base grid without significantly increasing overhead to computing resources (Casulli and Stelling, 2011; Loftis et al., 2015; Wang et al., 2014). A sub-grid is essentially a DEM imparted to a cross-scale hydrodynamic model, wherein calculations are performed on a coarser scale base DEM grid to conserve computational resources. Since presumably elevations do not change over the course of a model simulation, topographic heights and bathymetric depths may be stored on a sub-grid within a larger scale base (computational) grid to accurately compute fluid volumes flowing through each base grid cell in the process of shallow water transport (Wang et al., 2014). Subgrid modeling is a cutting-edge technology which is designed to use topographic measurements generated from light detection and ranging (lidar) data and bathymetry from sonar incorporated within a mosaicked DEM to form a detailed sub-grid of an otherwise conventional base grid model framework to simulate storm surge and inundation effectively and accurately within friction-dominated nonlinear systems (Casulli and Zanolli, 2012). The improved topographic representation stored within the model sub-grid allows for the effects of friction and total conveyance in a shallow water system to be determined efficiently and more accurately, resulting in better characterization of total inundation (Casulli and Stelling, 2011; Stelling and Kerncamp, 2010; Wang et al., 2015).

This methodology is significant because it provides a rational way to combine dense lidar measurements and bathymetry data into a high-resolution topobathymetric digital elevation model (TBDEM) to be stored within the model sub-grid. The sub-grid is nested within a coarser $(50 \mathrm{~m})$ base grid where computations are carried out to concurrently generate storm surge and hydrological transport model results (Figure 2). At NASA Langley Research Center, a network of numerous drainage ditches, on the order of $2-5 \mathrm{~m}$ wide, are utilized for draining excess water collected during weather events (Figures 3A-C). These ditches are part of the hydrological features that must be resolved within the model grid to preserve their shape in order to accurately model the extent, timing, and depth of the flood waters (Casulli, 2009). Precise representation of these drainage features is crucial to the accurate calculation of the fluid flux through each grid cell side, which ultimately determines the water depth and extent of flooding via distribution of water volume within each grid cell (Casulli and Stelling, 2011; Loftis, 2014).

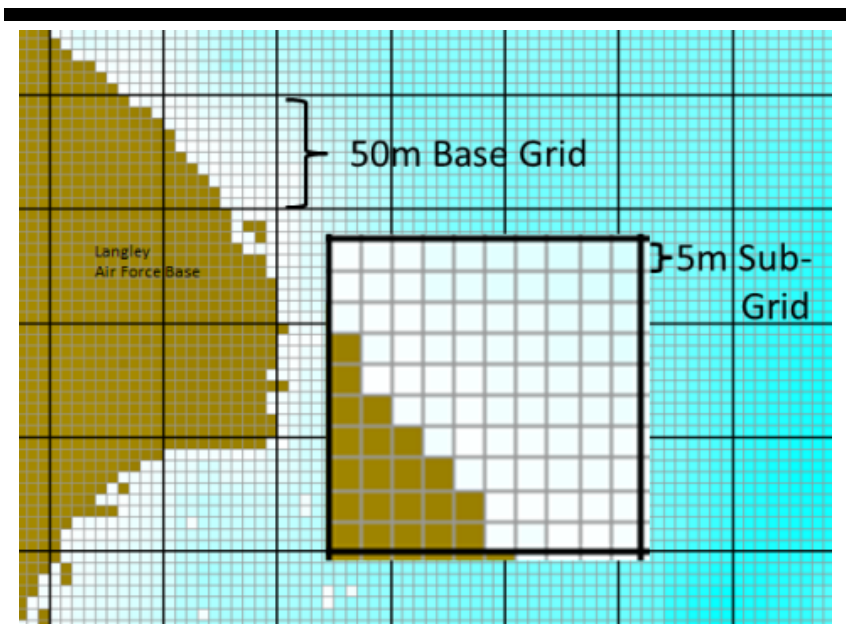

Figure 2. Model grid structure depicting a 50-m base grid with a $10 \times 10$ nested 5-m sub-grid showing the northeast tip of Langley Air Force Base with partly inundated (blue) and partly non-inundated (brown) grid cells. 

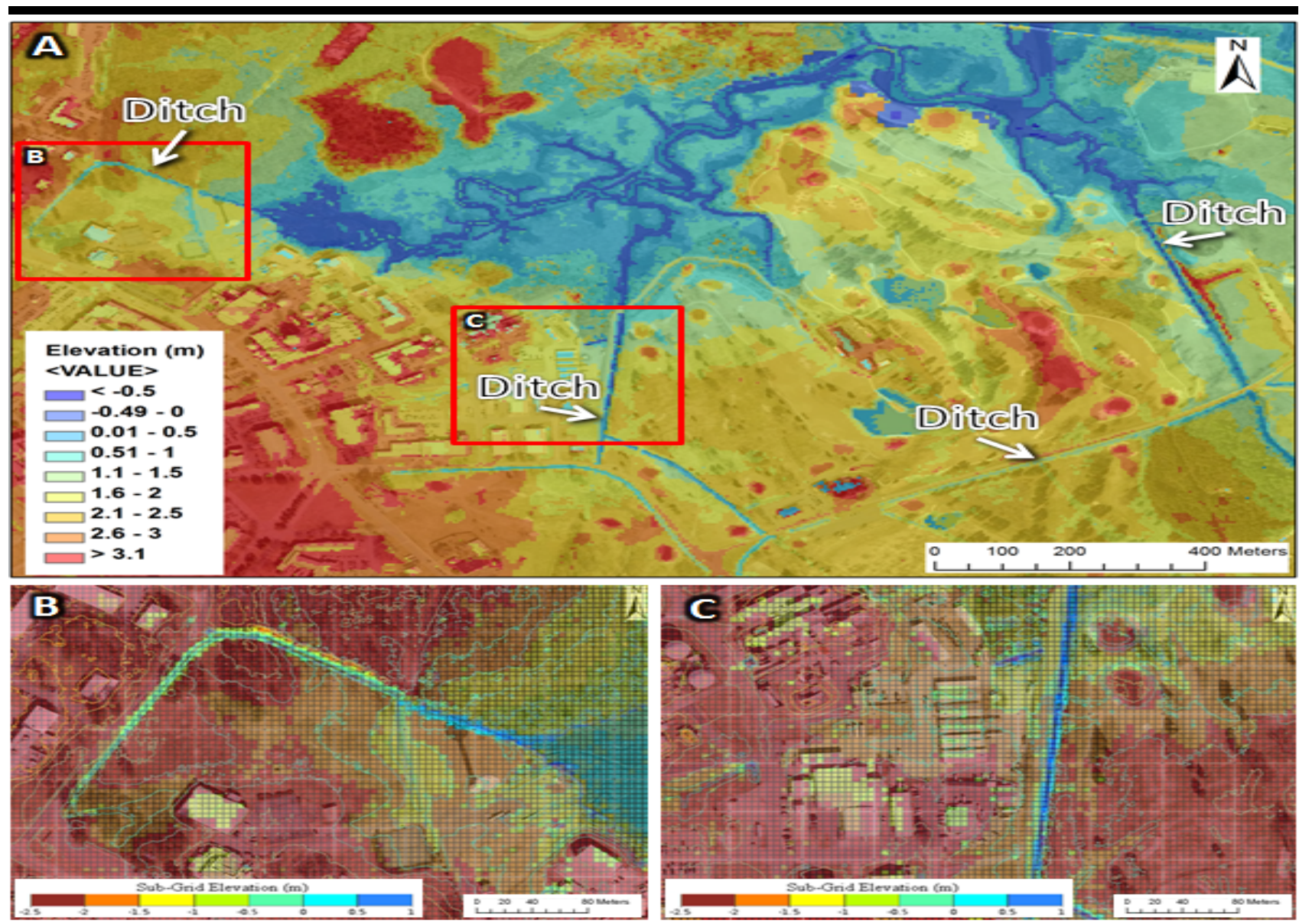

Figure 3. (A) Shaded relief map superposed with satellite imagery depicting overland drainage resolved via gridded lidar-derived DEM elevations; (B) drainage ditch following adjacent to Doolittle Road near NASA Building 1222 draining into the west end of Tabb Creek; and (C) drainage ditch adjacent to Gregg Road draining into the south end of Tabb Creek, both sufficiently resolved within the 5-m resolution nested sub-grid represented by the thin black grid lines in $3 \mathrm{~B}$ and $3 \mathrm{C}$.

Utilizing new sub-grid technology, it is possible to resolve ditches that are on the order of a few meters wide and at the same time be able to channel the rainfall into runoff to simulate the water budget and inundation for the entire Back River estuary influenced via external forcing (Figures 3B and 3C). The development of a hydrological transport model capable of flow accumulation into narrow drainage infrastructure requires the resolution afforded by lidar measurements. This study encompasses the development of a 50-m computational hydrodynamic model grid embedded with a specially developed $5 \mathrm{~m}$ DEM as a sub-grid to resolve critical drainage structures to improve flood modeling capabilities when coupled with precipitation. This is achieved by producing a Digital Surface Model (DSM) comprised of building heights at NASA Langley Research Center incorporated into a bare earth lidar-derived DEM, which is subsequently mosaicked with a TBDEM of the Greater Hampton Roads region (Loftis, Wang, and DeYoung, 2013). Possessing both the capabilities for storm surge and runoff simulations, the sub-grid model will then be applied to simulate two major storm events with significant inundation impacts observed at NASA Langley Research Center. Temporal comparison of model results will be conducted using a NASA tide gauge (NASA Langley GIS Team, 2010) during Hurricane Irene (2011). Also, geospatial analysis and statistical tests will ascertain whether the model can generate maximum inundation extent maps via comparison with Global Positioning System (GPS)-recorded spatial patterns of storm wrack line measurements. In 2003, Hurricane Isabel was the most devastating storm system to impact the Greater Hampton Roads region in the past 80 years (Gong, Shen, and Reay, 2007; Post $e t$ al., 2005; Wang et al., 2005), and will be used as a benchmark to run a series of simulations accounting for sea-level rise associated with climate change prediction scenarios specified by the Intergovernmental Panel on Climate Change (IPCC) (Meehl et al., 2007; Church et al., 2013).

\section{METHODS}

This section outlines the data used in addressing the incorporation of NASA lidar data into a high-resolution TBDEM for use with sub-grid modeling, and the development 
of a sub-grid model to test hydrological transport of precipitation using two ideal test cases. The subsequent results section introduces a recent storm event for inundation simulation, Hurricane Irene, with temporal and spatial comparisons using tide gauges and GPS-collected wrack line observations. These results are followed by addressing the vulnerability of the study area to the effects of sea-level rise using Hurricane Isabel as a reference benchmark in the discussion followed by the conclusion.

\section{Data Used}

The setup and development of the model domain for the Back River estuary is based upon the development of a DEM at $5 \mathrm{~m}$ resolution (Figure 4). A 1/3-arc-second resolution $(\sim 10 \mathrm{~m})$ TBDEM for the Virginia Beach and Greater Hampton Roads region associated with the National Oceanic and Atmospheric Administration (NOAA) Tsunami Inundation Project (Taylor et al., 2008) covers the entire watershed of the study area, but with insufficient resolution to adequately resolve fine scale drainage features (Figure 1). Thus, a 5-m mosaicked DEM was constructed throughout the study region sourced with (1) lidar topographic data and (2) the aforementioned TBDEM to be utilized as the base DEM for this modeling effort. The vertical datum was converted from mean high water to the North American Vertical Datum of 1988 (NAVD88) using VDatum (Parker et al., 2003) for use with inundation modeling (Yang et al., 2008). Supplementary bathymetric point data $(\sim 30 \mathrm{~m}$ average point spacing) were retrieved from two separate NOAA bathymetric surveys of the Back River estuary (NOAA NGDC, 2011) to cross-check and verify the bathymetry in the TBDEM during this process.

Lidar point cloud data ( $\sim 0.5 \mathrm{~m}$ point spacing) were acquired in 2005 by NASA with the focus of obtaining topographic measurements to generate high-resolution DEMs for NASA Langley Research Center and Langley Air Force Base (Figures $3 \mathrm{~A}-\mathrm{C})$. The data that were provided by the NASA Langley Geographic Information Systems (GIS) Team were spatially referenced horizontally to Virginia State Plane South NAD83 High Accuracy Reference Network (HARN) in meters, and vertically to NAVD88 in meters (NASA Langley GIS Team, 2011). The lidar las files were parsed as points and used to generate a single combined point file using las 2 txt from the LAStools toolset (Isenburg, 2012). The data sampled from the lidar point cloud acquired by NASA Langley Research Center $(\mathrm{RMSE}=5.5 \mathrm{~cm}$ in open terrain; $\mathrm{RMSE}=12.5 \mathrm{~cm}$ in vegetated terrain) had at least one elevation value per $\mathrm{m}^{2}$, for creation of a raster at $5 \mathrm{~m}$ resolution with few gaps in the data. Flight overlap bands were filtered out of the lidar point cloud along with erroneous reflected overwater measurements in ArcGIS 10 (ESRI, 2011), using a constrained shoreline polygon obtained from the Virginia Center for Coastal Resources Management (2013).

Vector building footprints within NASA Langley Research Center were furnished by the Langley GIS Team (NASA Langley GIS Team, 2011), and were incorporated into the subgrid using specified building heights above NAVD88 or a default value of $10 \mathrm{~m}$ where building height data was missing. This was done to account for the inherent impediment buildings pose to storm surge along with the form drag caused by flow around buildings (Loftis et al., 2015). The vector building footprints were used to increase the height of the DEM by the provided building heights in places enveloped by the building polygons. The buildings were originally filtered out by selecting the bare earth lidar measurements, and this method effectively added the buildings back into the DEM while minimizing vertical occlusion from taller buildings and infrastructure. In essence, a DSM was generated from the bare earth DEM and building heights, which subsequently was incorporated into the bare earth elevation surface. The resulting DSM was overwritten on top of the topographic values from the Virginia Beach TBDEM obtained from Taylor et al. (2008) to provide added topographic resolution for the region surrounding NASA Langley Research Center and Langley Air Force Base.

Data used to drive the hydrodynamic sub-grid model include (1) water elevations in the form of predicted tide and storm tide, (2) wind and pressure as atmospheric forcing, (3) precipitation as an atmospheric fluid source, and (4) infiltration through the soil to balance precipitation as a fluid sink (Figure 4). Storm tide

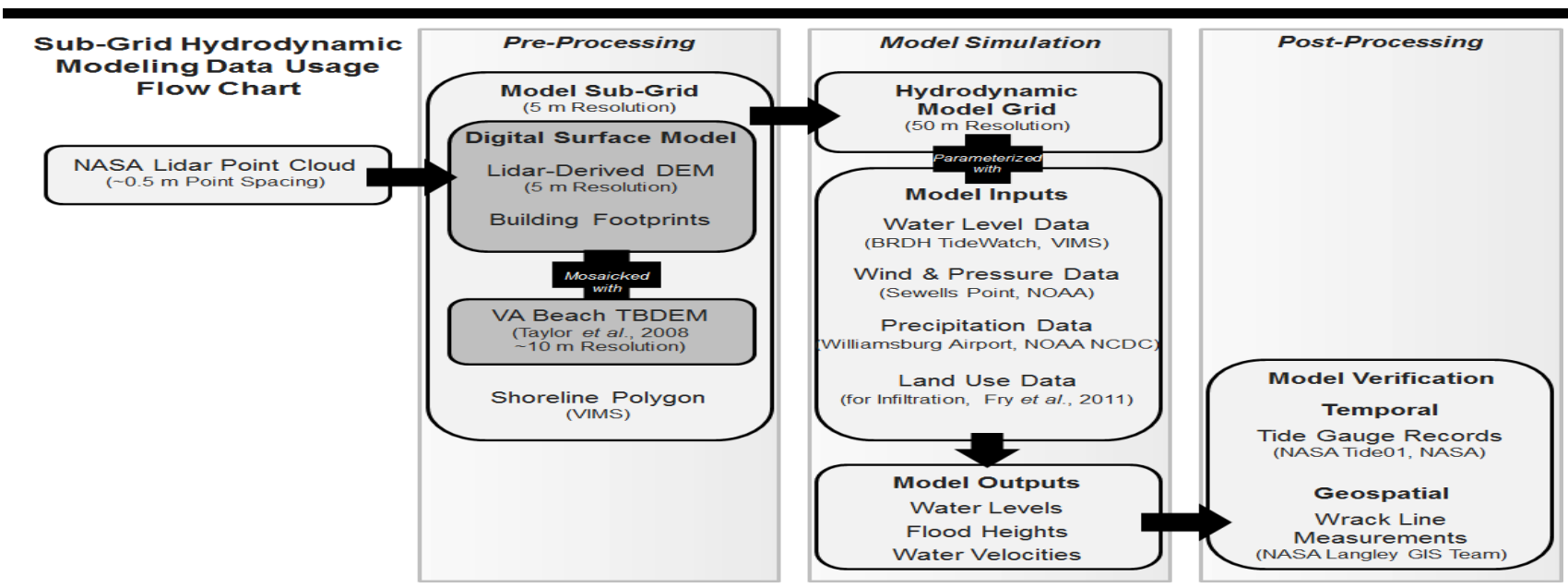

Figure 4. Sub-grid hydrodynamic modeling data usage flow chart outlining all significant data sources used in this study. 
was forced along the open boundary on the easternmost edge of the domain at the mouth of Back River using data from Dandy Haven Marina (Boon, 2008). Wind and pressure data were retrieved in $\mathrm{m} / \mathrm{s}$ from NOAA observations at Sewell's Point, VA (NOAA Tides and Currents, 2011). Precipitation inputs were obtained from hourly measurements from the NOAA National Climatic Data Center collection station at the Newport News/Williamsburg Airport (NOAA NCDC, 2011). To balance the precipitation source, a spatially-varying infiltration rate was generated using land cover data from the 2006 National Land Cover Database (Fry et al., 2011) and will be discussed later in the methods section.

Upon completion of model simulations, a water level gauge (NASA Tide01) was utilized to evaluate the temporal variability of 2011 Hurricane Irene and assess the vertical flood height accuracy of the model (NASA Langley GIS Team, 2010). Horizontal accuracy was ascertained using GPS measurements of wrack line debris collected throughout NASA Langley Research Center by the Langley GIS Team immediately following the storm on August 29, 2011, for a rigorous geospatial comparison for sub-grid model simulations without and with soil infiltration (NASA Langley GIS Team, 2011).

\section{Hydrodynamic Model Grid Generation}

A 5-m resolution DEM was generated from the airborne lidar elevation data to efficiently and accurately resolve fine scale hydrologic features such as creeks and narrow drainage ditches within NASA Langley Research Center. This DEM was then mosaicked with the $\sim 10-\mathrm{m}$ resolution TBDEM containing topography and bathymetry of surrounding areas outside of NASA Langley Research Center obtained from Taylor et al. (2008) depicted in Figure 1. A 10-m buffer was used to minimize conflicting overlap to ensure a seamless cross-shore transition between the disparate multi-temporal sources of topography from the lidar-derived DEM, the TBDEM from Taylor et al. (2008), and NOAA's bathymetry measurements, while still preserving precise representation near shoreline drainage features. Most differences in land elevation between the lidar measurements and the Virginia Beach TBDEM were $<10 \mathrm{~cm}$, creating a nearly seamless transition between the two elevation data sources. The preservation of shoreline slopes is vital for the mapping of fluid flux through each grid cell side of the sub-grid model, which ultimately regulates the water depth and extent of inundation via distribution of water volume within each model grid cell.

A 50-m resolution computational hydrodynamic model grid was produced to envelop the Back River watershed. The merged 5-m resolution TBDEM was imported into grid-generation software (Lippert, 2010) to generate the model sub-grid. The sub-grid was constructed over a model domain covering the Back River estuary surrounding NASA Langley Research Center with an open boundary at the mouth of the Back River leading into the Chesapeake Bay (Figure 1). The model's computational base grid was constructed using $50-\mathrm{m}$ resolution grid cells, with 100 nested $5 \times 5 \mathrm{~m}$ sub-grid cells within each base grid cell (Figure 2). This $50-\mathrm{m}$ resolution base grid was chosen so that the main stem of the Back River channel would have multiple 50-m computational base grid cells across the width of the estuary for proper calculation of water volume transport into and out of the system. The sub-grid scaling was chosen such that the lidar-derived topographic DEM would minimize stretching and smoothing effects during interpolation onto the sub-grid mesh, which would potentially invite computational error due to distortion (Loftis, 2012; Wang et al., 2014). The density of the final-return lidar point cloud could be utilized to produce even higher resolution DEMs, and subsequently source sub-grid scales down to $1-\mathrm{m}$ horizontal resolution. However, the error associated with lidar data collection methods, assuming the most accurately calibrated instrumentation, still may include vertical errors on the order of $0-10 \mathrm{~cm}$ along spatially uniform terrain and $10-30 \mathrm{~cm}$ in heavily vegetated areas and urban environments, and the lidar measurements used in this study fall within these uncertainty ranges (Huising and Gomes Pereira, 1998; Webster and Dias, 2006).

\section{Development of a Sub-Grid Hydrological Transport Model}

The resulting sub-grid hydrodynamic model functions as a continuous time model using a 5-minute time interval to simulate the Back River water budget given the various landscapes resolved in the watershed. The sub-grid model uses a bi-level disaggregation scheme wherein preliminary sub-basin identifications are carried out based upon topographic criteria, followed by further discretization using land use type considerations (Casulli and Stelling, 2011). Given that flooding as a result of heavy rainfall is a recurrent nuisance in the coastal plain of Virginia (Virginia Institute of Marine Science, 2013; Sweet et al., 2014), the added resolution afforded by the nested sub-grid within each coarse computational grid cell should provide sufficient resolution to resolve ditches and other overland drainage infrastructure to accurately calculate flow accumulation for simulation of runoff. Tests were designed and performed to determine whether the rainfall over land accumulated in the ditches/channels and whether 5-m resolution was high enough resolution for the model sub-grid to resolve trenches to adequately simulate the diversion of runoff induced by heavy precipitation.

When precipitation is prescribed as an atmospheric input, the hydrodynamic model becomes a runoff model to describe the rainfall-runoff relations of a rainfall catchment area, watershed, and drainage basin (Gong et al., 2009). More precisely, it produces the surface runoff hydrograph as a response to a rainfall hydrograph provided as a model input. Thus, the model calculates the conversion of rainfall into runoff. Often numerical models have separate modules to address individual steps in the simulation process. The most common module is a subroutine for calculation of surface runoff (Casulli and Zanolli, 1998), allowing variation in land use type, topography, soil type, vegetative cover, precipitation, and land management practice such as the application rate of a fertilizer (Loftis et al., 2015; Wang et al., 2005). However, in this study, the land use is assumed to be homogeneous and the soil already saturated during the storm condition, as was the case during both Hurricane Irene and Hurricane Isabel.

Ideal test simulations for precipitation were utilized to test the input of rainfall into the model in two separate cases: one using an open flow basin with rainfall shown in Figure 5A, and a closed flow basin with rainfall in Figure 5B. An ideal ditch was designed for both simulations with sloping sides angled into the 

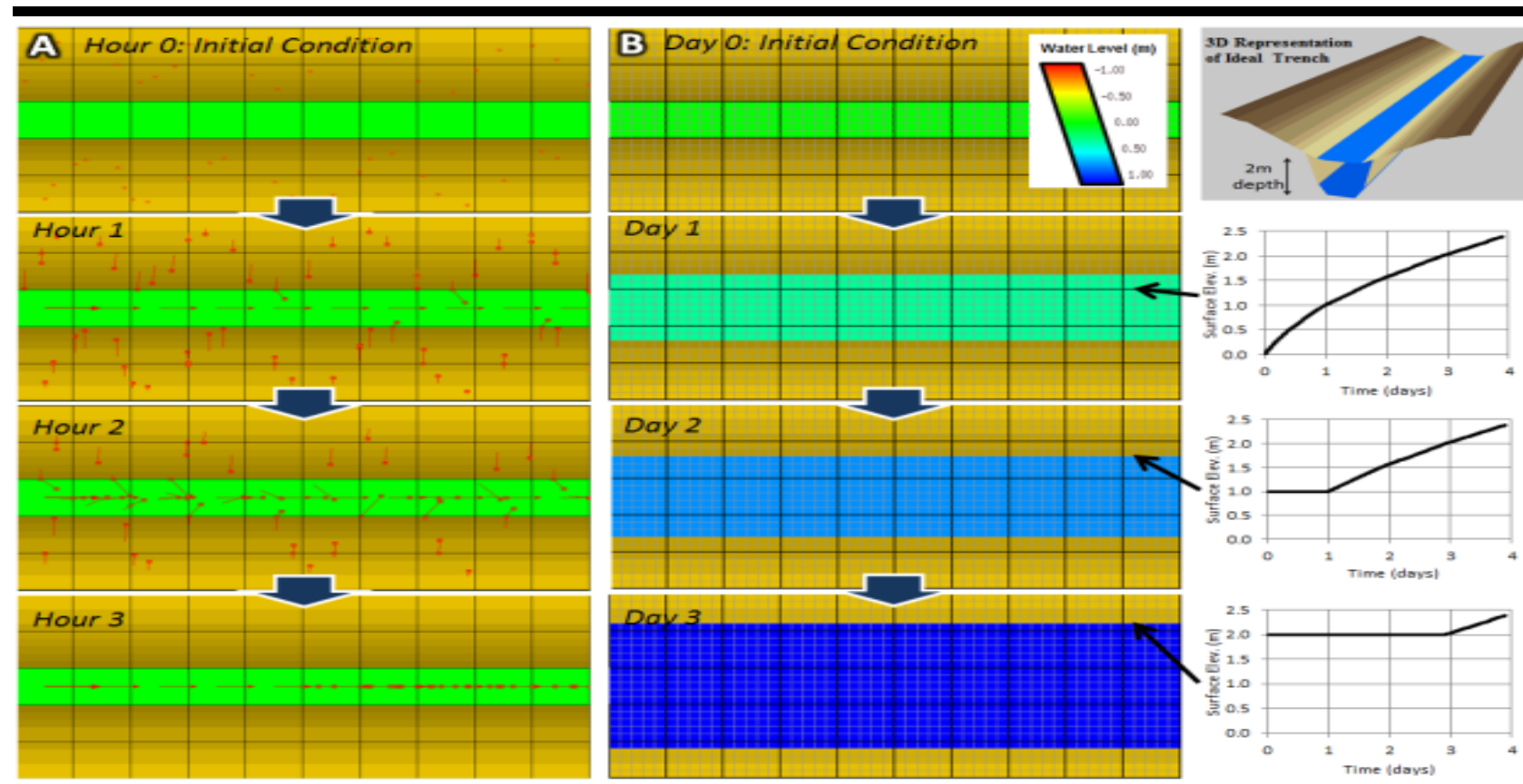

Figure 5. (A) Top-down view of an ideal test case for precipitation in an open flow basin using a prescribed $0.5 \mathrm{~m} / \mathrm{s}$ flow from the left. Precipitation transports red particles initially placed on land into the ditch and out of the basin over a three-hour period. (B) Ideal test case in a fully enclosed basin which allows rainfall to collect and water volume to properly accumulate over time. Both simulations specify a rainfall rate of $25 \mathrm{~mm} / \mathrm{hr}$. The top right inset depicts a 3-D representation of the sub-grid in ArcScene GIS (ESRI, 2011).

basin as depicted in the inset of Figure 5 . The model grid is shaped like a gradually sloping trough with a depth of $2 \mathrm{~m}$ in the channel. The banks of the trough gradually slope into the central channel with a maximum elevation of $3 \mathrm{~m}$ on each side. The use of high-resolution lidar-derived elevations augments the potential resolution of the sub-grid model, thus the precise representation of these drainage features in the DEM is imperative. Appropriately resolving drainage features permits correct computation of fluid flux through each grid cell side. The fluid flux, in turn, controls the water depth and extent of flooding through the spatial distribution of water volume within each grid cell.

\section{Tidal and Atmospheric Model Forcing}

Tides were forced along the open boundary on the easternmost edge of the domain at the mouth of the Back River into Chesapeake Bay (Boon, 2008). The north bank of the estuary comprises the southeastern edge of Poquoson, with the south bank being adjacent to the Grandview Park spit in Hampton, VA, as shown in Figure 1. The tidal input for Hurricane Irene was collected $3 \mathrm{~km}$ from the model's open boundary at Dandy Haven Marina (part of a suite of Virginia Institute of Marine Science (VIMS) TideWatch stations throughout Chesapeake Bay), and interpolated to a 5-minute time step (Boon, 2008).

Wind data were retrieved in $\mathrm{m} / \mathrm{s}$ from NOAA observations at Sewell's Point, VA (NOAA Tides and Currents, 2011), and prepared as a uniform input throughout the domain for each of the storm scenarios. $\mathrm{U}$ and $\mathrm{V}$ wind velocities were extracted and wind fields were interpolated to 5-minute intervals with start and end times of 00:00 on 08/01/2011 and 00:00 on 09/01/2011, GMT, for Hurricane Irene. Atmospheric pressure data in millibars were obtained for the same time periods from NOAA observations at Sewell's Point, VA, and were subsequently converted to Pascals, and prescribed as a uniform atmospheric pressure input throughout the domain. Precipitation inputs were interpolated from hourly measurements from the NOAA National Climatic Data Center collection station at the Newport News/ Williamsburg Airport (NOAA NCDC, 2011) $<2 \mathrm{~km}$ from NASA Langley Research Center (Figure 1).

\section{Ideal Test Cases for Precipitation}

The parameters for the open flow basin with rainfall ideal test case include a flux boundary condition with a constant prescribed $0.5 \mathrm{~m} / \mathrm{s}$ flow on the left edge of the grid in Figure 5A with no forcing at the open boundary on the right edge. A constant $25 \mathrm{~mm} / \mathrm{hr}$ precipitation input was designated for a 72 hour simulation. Over the three-day simulation, the sub-grid model's particle tracking mode was utilized to place particles on the top and bottom banks of the ideal trough-shaped domain to allow precipitation to transport the particles into the channel and be transported out of the domain. The particles, represented as red dots, were arbitrarily placed at a variety of elevations between 0-2 $\mathrm{m}$ above the water level in the basin to demonstrate that precipitation will gravitationally transport the particles perpendicular to the contours into the trough-shaped basin and out of the domain as runoff. This scenario was designed to demonstrate the model's capability of transporting precipitation 
into an unobstructed, free-flowing drainage ditch back to the neighboring river system.

Another ideal test case for rainfall was made in a fully enclosed basin with walls blocking transport out of the domain on both sides of the idealized sloping trough with no prescribed flux boundary condition on the left edge of the grid, and no forcing at the clamped open boundary on the right edge. The same constant $25 \mathrm{~mm} / \mathrm{hr}$ precipitation input was prescribed over a 72-hour simulation shown in Figure 5B. This test case was designed to test the conservation of mass and ascertain that precipitation would accumulate in a ditch if there was no outlet to allow water to escape. This scenario successfully validated the model's ability of collecting precipitation over time and allowed the user to compute the volume of water collected over time in a generalized bathtub-style simulation in preparation for simulating real world flooding applications.

\section{Geospatial Comparison without and with Soil Infiltration}

After Hurricane Irene, detailed GPS measurements of wrack line debris were collected throughout NASA Langley Research Center by the Langley GIS Team on August 29, 2011, in NAD83 HARN Virginia State Plane South coordinates. The wrack line positions are considered to be the maximum extent of the floodwaters during the storm event, although strictly speaking, some of the debris may have been caught due to the effect of friction and subsequently may not have traveled as far. This difference, however, is likely small enough to be neglected.

The wrack line measurements collected at NASA Langley Research Center in the aftermath of Hurricane Irene provided a unique observation dataset that can be utilized to assess the maximum extent of inundation, both horizontally and vertically. In the context of a point-to-point vertical inundation comparison, it was reasonable to assume that the water layer thickness was zero at the GPS-observed wrack line locations during the peak inundation period of the storm. These were compared with the modeled water layer thickness, which was calculated by the maximum water surface elevation minus the local topography at each wrack line point. Ideally, the modeled value should be close to $0 \mathrm{~m}$ for a perfect $100 \%$ match. As such, the following simple Equation 1 is employed to quantify \% overprediction by the model:

$$
\% \text { Model Overprediction }=\left(\left(\frac{S}{W}\right) \times 100\right)-100
$$

where the ratio of average local sub-grid DEM height $(S)$ to average modeled water elevation $(W)$ is multiplied by 100 , then subtracted by 100 to evaluate error in supposed water elevation $(0 \mathrm{~m})$ at each of the surveyed wrack line points to quantify differences in water elevations near sea level.

One of the main assumptions in the "without infiltration" approach is that the ground is completely saturated, so there is no water infiltration. In practice, precipitation falling on the land surface can infiltrate into the pervious soil. Soil has a finite capacity to absorb water. The infiltration capacity varies not only from soil to soil, but is also different for dry versus moist conditions based upon the hydraulic conductivity gradient in the same soil (Burghardt, 1994). If fluid is allowed to infiltrate into groundwater through the sediment/water interface, the degree of overprediction associated with the precipitation input from the model may be more balanced. In other words, inundation predictions "without infiltration" represent the worst case scenario flood estimates, and overprediction is expected as a result of neglecting this sink (Fetter, 1994; Mark et al., 2004).

To implement spatially-varying infiltration, the rational equation commonly utilized for describing the rainfall-runoff relationship is used (American Soc. of Civil Engineers, 1986). When the rainfall rate and runoff coefficient are considered constant in time, infiltration could be expressed as Equation 2:

$$
\text { Infiltration }=(1-C) \times I \times A
$$

where $I$ is the average rainfall rate, $A$ is the drainage area, and $C$ is the (dimensionless) runoff coefficient.

The spatially-varying infiltration rate in $\mathrm{mm} / \mathrm{hr}$ during Hurricane Irene at NASA Langley Research Center was generated using land cover data from the 2006 National Land Cover Database (Fry et al., 2011) and resampled to 50-m resolution such that each base grid cell was prescribed a unique infiltration rate within the model, as shown in Figure 6. (Details of the U.S. Geological Survey NLCD land cover data and runoff factor for the rational equation can be found in the appendix.) Based upon a spatially-varying infiltration rate, higher percentages of land cover with vegetation equates to greater absorption into the soil; conversely, less vegetation and greater percentages of urban infrastructure including paved surfaces, streets, drainage structures, and runways equates to more impervious surfaces for a lower infiltration rate.

\section{RESULTS}

The NASA Tide01 and Back River Dandy Haven tide gauges were utilized to evaluate the temporal variability of Hurricane Irene. The NASA Tide01 gauge was installed in 2010, and the Back River Dandy Haven Gauge was installed in 2008. Their locations are noted within the model domain in Figure 1 (NASA Langley GIS Team, 2010; 2012). A temporal comparison of observed results at the NASA Tide01 gauge yielded a correlation of $\mathrm{R}^{2}=0.9714$ and a root mean square error (RMSE) of $0.079 \mathrm{~m}$ with an observed maximum inundation peak of 1.656 $\mathrm{m}$ above NAVD88 as shown in Figure 7A. This resulted in an average inundation thickness of approximately $0.39 \mathrm{~m}$ in the neighboring areas of the tidal creek surrounding the gauge. A peak precipitation rate of $46 \mathrm{~mm} / \mathrm{hr}$, observed at the Newport News/Williamsburg Airport on August 28, 2011, at 05:00 GMT, is also shown in Figure 7B, coinciding with the storm surge peak (NOAA NCDC, 2011).

\section{Spatial Comparison Using Wrack Line Measurements}

The results of the simulation without infiltration are presented first. Examples of the wrack line measurements at three separate flood impact sites were plotted in Figures $6 \mathrm{~A}-\mathrm{C}$, with the associated GPS measurements presented in Tables 1-3. The inundation impact site featured in Figure $8 \mathrm{~A}$ is located near the tidal tributary to the Back River estuary in the central region of NASA Langley. The wrack line contains 35 points with a localized average modeled water elevation of $1.802 \mathrm{~m}$ (Table 4) with an average difference/water thickness of $0.128 \mathrm{~m}$ (Table 1). The wrack line shown in Figure $8 \mathrm{~B}$ is located adjacent to a 


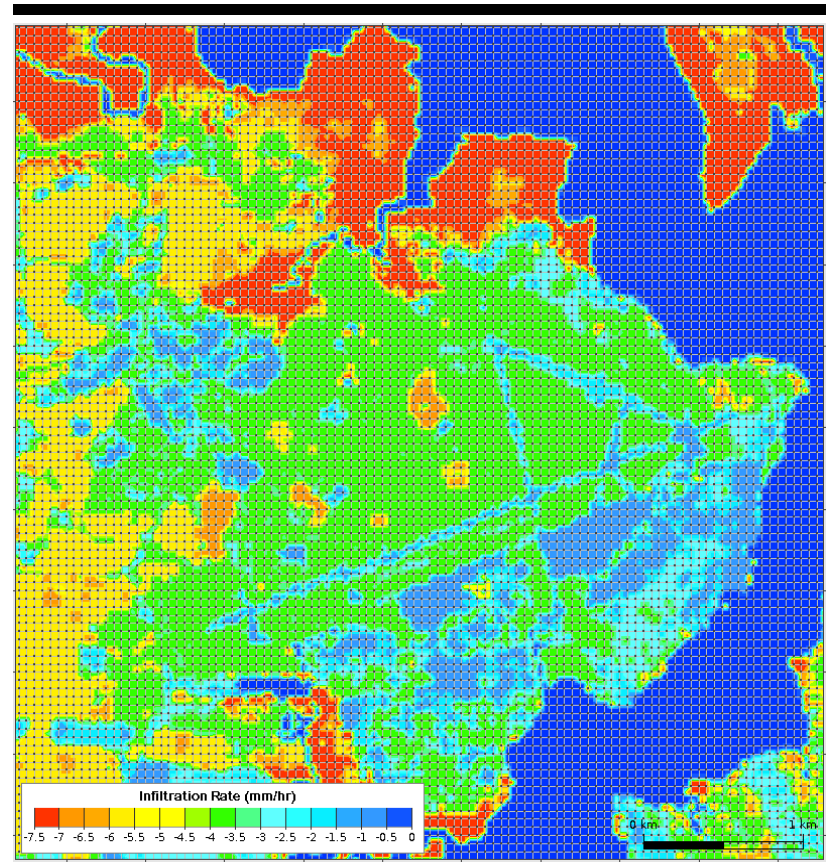

Figure 6. Example of a spatially-varying infiltration rate in $\mathrm{mm} / \mathrm{hr}$ at NASA Langley Research Center and Langley Air Force Base using the 2006 National Land Cover Database's land cover data superposed with the 50-m hydrodynamic model base grid for reference.

meandering tidal creek connecting the Big Bethel Reservoir to the Back River estuary close to the location of Langley Tide Gauge 1 in the north end of Langley near building 1196 adjacent to a drainage creek. This wrack line consists of 14 unique measurements with an average modeled water elevation of 1.780 $\mathrm{m}$ (Table 4) and an average difference/water thickness of 0.231 $\mathrm{m}$ (Table 2). Figure $8 \mathrm{C}$ illustrates a wrack line site, located parallel to the west end of building 1257 adjacent to the meandering tidal creek on the north end of NASA Langley near building 1258. The wrack line is populated with 7 points with a localized average modeled water elevation of $1.800 \mathrm{~m}$ (Table 4) and an average difference/water thickness of $0.168 \mathrm{~m}$ (Table 3 ). Overall, vertical comparisons showed that water elevations at Sites A, B, and C were overpredicted by approximately $10 \%$ without consideration of infiltration (Table 4).

Tests employing a spatially-varying infiltration rate exhibited marked improvement in comparison with wrack line observations, as shown in columns 6 and 7 of Tables 1-3 (Figures 6A-C). The incorporation of a spatially-varying infiltration rate improves the vertical difference from an average of $0.128 \mathrm{~m}$ (without infiltration) to $-0.052 \mathrm{~m}$ (with spatially varying infiltration) at site $\mathrm{A}$ (Figure $8 \mathrm{~A}$ and Table 1). The overprediction value is negative, indicating that the model now underpredicts the amount of flood elevation at site A by $1.48 \%$ (Table 4). Site B shows improvement in vertical difference from $0.231 \mathrm{~m}$ (without infiltration) to $0.147 \mathrm{~m}$ (with spatially varying infiltration), as shown in Figure 8B and Table 2. Likewise, at site $\mathrm{C}$, the result is augmented from $0.168 \mathrm{~m}$ (without
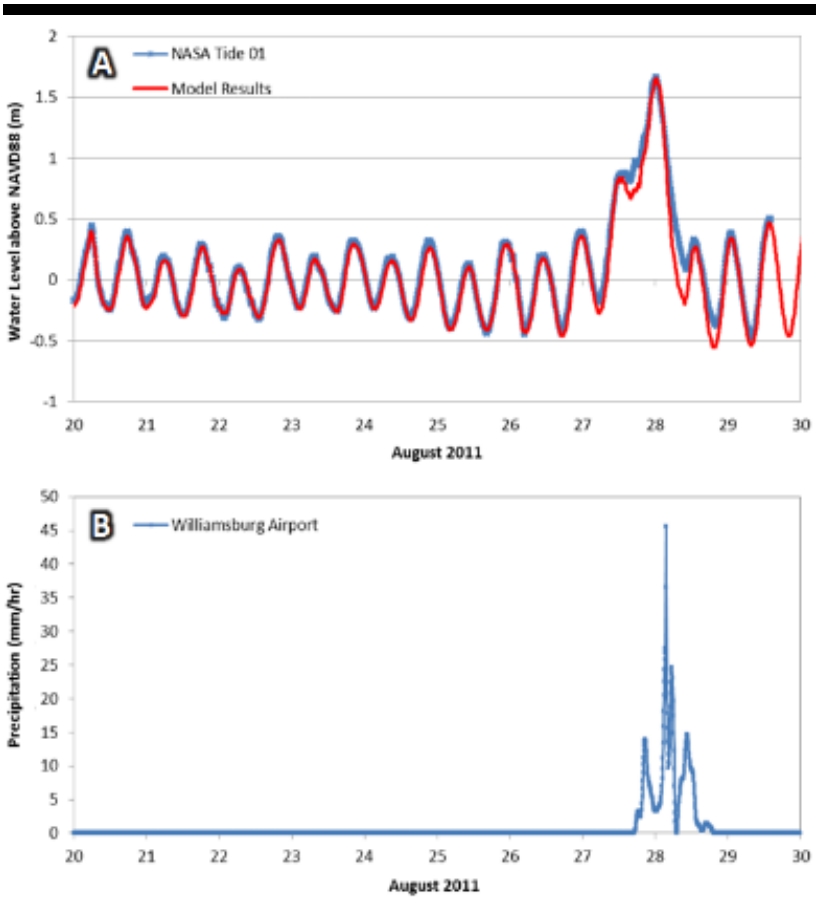

Figure 7. (A) Temporal comparison (GMT) of observed results via NASA Tide01 and sub-grid results $\left(\mathrm{R}^{2}=0.97\right.$; $\left.\mathrm{RMSE}=0.079 \mathrm{~m}\right)$ with an observed peak of $1.656 \mathrm{~m}$ above mean sea level during Hurricane Irene. (B) Precipitation input data from Newport News/Williamsburg Airport shown for Hurricane Irene with a peak observed rainfall rate of $46 \mathrm{~mm} / \mathrm{hr}$ August 28, 2011, at 05:00 GMT.

infiltration) to $0.103 \mathrm{~m}$ (with spatially-varying infiltration), as shown in Figure 8C and Table 3. Overall, the vertical water elevation difference improved from approximately $10 \%$ error (without infiltration) to within $2-5 \%$ error with spatially varying infiltration (Table 4).

Corresponding to the implementation of spatially-varying infiltration, the average difference in horizontal distance between the modeled maximum extents (depicted as red lines in Figure 8 ) and the 35 wrack line measurements at Site A was 8.5 $\mathrm{m}$. Figure $8 \mathrm{~B}$ shows an average overprediction of $4 \mathrm{~m}$ using 14 wrack line records, and Figure $8 \mathrm{C}$ depicts the best horizontal maximum inundation comparison, following the 7 wrack line points within an average distance of $1 \mathrm{~m}$. Each of these featured sites is in close proximity to a drainage ditch, which was properly resolved within the model sub-grid via incorporation of lidar measurements.

\section{DISCUSSION}

Observed results at Sewells Point, VA, and sub-grid results yielded an observed peak of $2 \mathrm{~m}$ above mean sea level. A peak observed rainfall rate of $28 \mathrm{~mm} / \mathrm{hr}$ was observed during Hurricane Isabel on September 18, 2003, at 20:00 GMT at the Newport News/Williamsburg Airport (NOAA NCDC, 2003). Rainfall is an important parameter to consider in inundation modeling. 

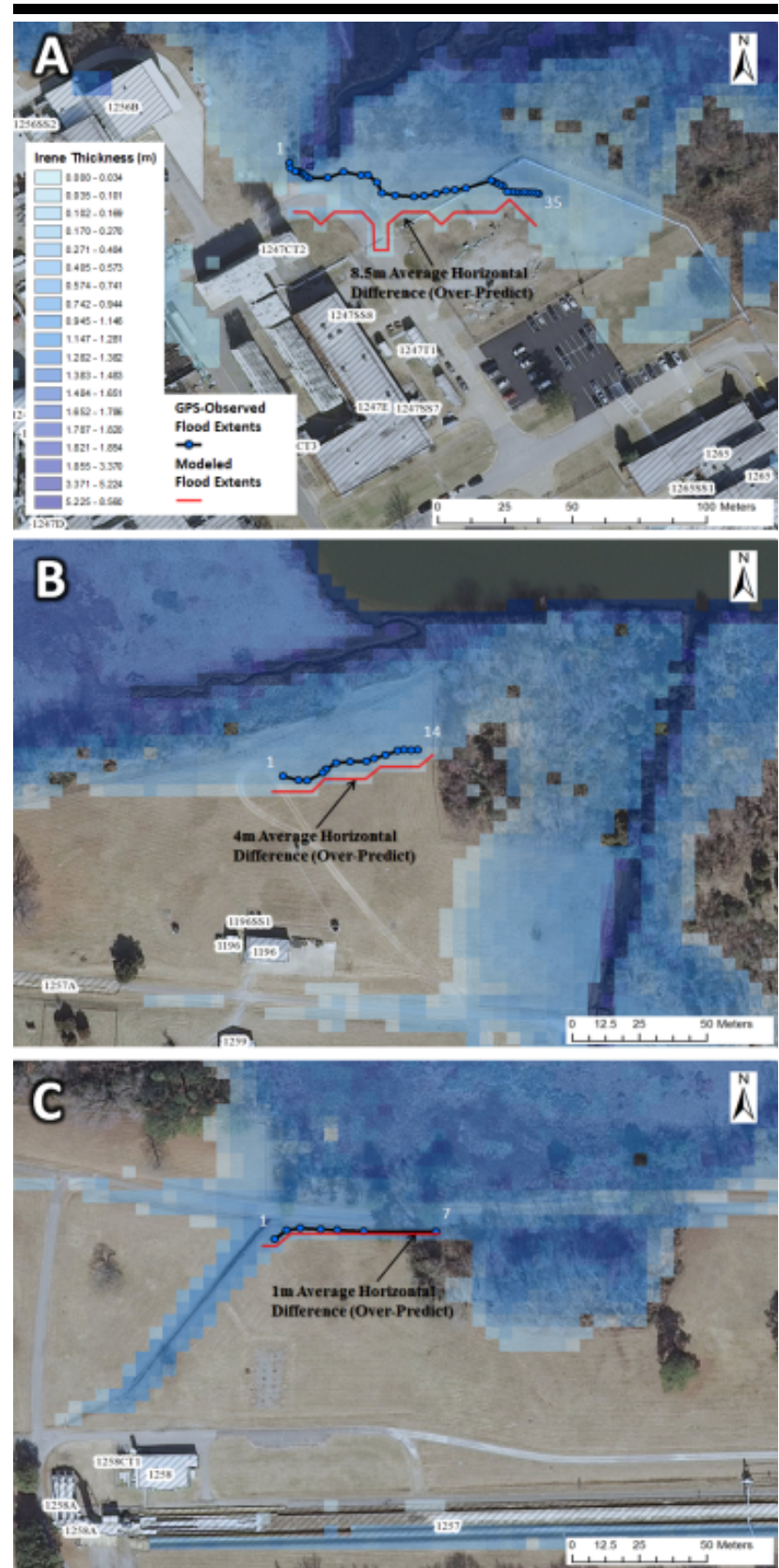

Figure 8. Spatial comparison of modeled maximum inundation extents (with precipitation) with GPS-recorded wrack line records after Hurricane Irene at three separate flood impact sites within NASA Langley Research Center. Depths correspond to wrack line thicknesses in Tables 1-3.

\section{Impact of Precipitation during Hurricane Isabel}

To appropriately address tropical and extra-tropical storm systems for both flooding extent and duration, precipitation is an invaluable parameter to consider in hydrodynamic modeling in the coastal plain (Carpenter and Georgakakos, 2004; Hwang et
Table 1. GPS-recorded wrack line data related to Figure $8 A$ with NAD83 HARN Virginia State Plane South coordinates for northing and easting $(m)$, the difference between GPS observations and sub-grid model predicted inundation thickness without and with spatially varying infiltration through the soil ( $m$ ), and horizontal distance difference $(m)$. Aggregate statistics for average difference and standard deviation are also provided for each wrack line comparison.

\begin{tabular}{|c|c|c|c|c|c|c|}
\hline \# & $\begin{array}{l}\text { Northing } \\
(\mathrm{m})\end{array}$ & $\begin{array}{l}\text { Eas ting } \\
(\mathrm{m})\end{array}$ & $\begin{array}{c}\text { DEM } \\
\text { Height } \\
(\mathrm{m})\end{array}$ & $\begin{array}{l}\text { Difference } \\
\text { without } \\
\text { Infiltration } \\
\text { (m) }\end{array}$ & $\begin{array}{l}\text { Difference } \\
\text { with } \\
\text { Infiltration } \\
\text { (m) }\end{array}$ & $\begin{array}{l}\text { Ho rizo ntal } \\
\text { Dis tance } \\
\text { Diffe rence } \\
\text { (m) }\end{array}$ \\
\hline 1 & 1086519.4 & 3688608.6 & 1.63 & 0.175 & -0.005 & 17.75 \\
\hline 2 & 1086517.4 & 3688609.0 & 1.68 & 0.123 & -0.057 & 15.83 \\
\hline 3 & 1086516.1 & 3688610.8 & 1.70 & 0.100 & -0.080 & 15.57 \\
\hline 4 & 1086516.1 & 3688611.6 & 1.68 & 0.119 & -0.061 & 15.54 \\
\hline 5 & 1086516.1 & 3688612.5 & 1.67 & 0.137 & -0.043 & 15.56 \\
\hline 6 & 1086515.5 & 3688613.6 & 1.70 & 0.107 & -0.073 & 14.27 \\
\hline 7 & 1086514.4 & 3688614.8 & 1.69 & 0.116 & -0.064 & 12.93 \\
\hline 8 & 1086513.6 & 3688616.1 & 1.71 & 0.096 & -0.084 & 12.72 \\
\hline 9 & 1086514.0 & 3688623.0 & 1.72 & 0.078 & -0.102 & 12.57 \\
\hline 10 & 1086516.5 & 3688628.9 & 1.74 & 0.063 & -0.117 & 13.72 \\
\hline 11 & 1086515.5 & 3688635.4 & 1.71 & 0.097 & -0.083 & 14.98 \\
\hline 12 & 1086515.6 & 3688638.0 & 1.72 & 0.079 & -0.101 & 14.88 \\
\hline 13 & 1086512.8 & 3688641.3 & 1.67 & 0.135 & -0.045 & 10.79 \\
\hline 14 & 1086508.6 & 3688643.5 & 1.72 & 0.085 & -0.095 & 10.65 \\
\hline 15 & 1086507.8 & 3688648.4 & 1.70 & 0.102 & -0.078 & 4.93 \\
\hline 16 & 1086507.5 & 3688655.4 & 1.69 & 0.108 & -0.072 & 4.39 \\
\hline 17 & 1086508.1 & 3688659.2 & 1.68 & 0.121 & -0.059 & 4.49 \\
\hline 18 & 1086509.0 & 3688663.6 & 1.70 & 0.103 & -0.077 & 5.58 \\
\hline 19 & 1086510.5 & 3688667.2 & 1.70 & 0.107 & -0.073 & 6.60 \\
\hline 20 & 1086510.8 & 3688670.6 & 1.69 & 0.108 & -0.072 & 5.81 \\
\hline 21 & 1086511.7 & 3688674.6 & 1.65 & 0.156 & -0.024 & 6.63 \\
\hline 22 & 1086515.1 & 3688683.8 & 1.63 & 0.168 & -0.012 & 4.75 \\
\hline 23 & 1086514.8 & 3688684.6 & 1.64 & 0.167 & -0.013 & 4.71 \\
\hline 24 & 1086514.2 & 3688685.8 & 1.65 & 0.155 & -0.025 & 4.14 \\
\hline 25 & 1086513.4 & 3688687.2 & 1.65 & 0.148 & -0.032 & 3.68 \\
\hline 26 & 1086513.1 & 3688688.4 & 1.67 & 0.136 & -0.044 & 3.29 \\
\hline 27 & 1086510.8 & 3688690.1 & 1.65 & 0.155 & -0.025 & 1.68 \\
\hline 28 & 1086510.9 & 3688691.6 & 1.67 & 0.130 & -0.050 & 2.21 \\
\hline 29 & 1086510.7 & 3688693.0 & 1.66 & 0.145 & -0.035 & 2.62 \\
\hline 30 & 1086510.6 & 3688694.4 & 1.63 & 0.170 & -0.010 & 4.31 \\
\hline 31 & 1086510.9 & 3688696.0 & 1.62 & 0.187 & 0.007 & 5.60 \\
\hline 32 & 1086510.7 & 3688697.6 & 1.67 & 0.131 & -0.049 & 6.28 \\
\hline 33 & 1086510.8 & 3688699.2 & 1.65 & 0.153 & -0.027 & 6.78 \\
\hline 34 & 1086510.7 & 3688700.7 & 1.64 & 0.159 & -0.021 & 8.21 \\
\hline 35 & 1086510.4 & 3688701.8 & 1.64 & 0.167 & -0.013 & 9.33 \\
\hline \multirow{2}{*}{\multicolumn{4}{|c|}{$\begin{array}{l}\text { Avr. Difference } \\
\text { Std. Deviation }\end{array}$}} & 0.128 & -0.052 & 8.68 \\
\hline & & & & 0.032 & 0.032 & 4.90 \\
\hline
\end{tabular}

Table 2. GPS-recorded wrack line data corresponding with Figure 8B.

\begin{tabular}{|c|c|c|c|c|c|c|}
\hline \# & $\begin{array}{l}\text { No rthing } \\
(\mathrm{m})\end{array}$ & $\begin{array}{l}\text { Eas ting } \\
\quad(\mathrm{m})\end{array}$ & $\begin{array}{c}\text { DEM } \\
\text { Height } \\
(\mathrm{m})\end{array}$ & $\begin{array}{l}\text { Difference } \\
\text { witho ut } \\
\text { Infiltration } \\
(\mathrm{m})\end{array}$ & $\begin{array}{l}\text { Difference } \\
\text { with } \\
\text { Infiltration } \\
(\mathrm{m})\end{array}$ & $\begin{array}{l}\text { Ho rizontal } \\
\text { Dis tance } \\
\text { Diffe rence } \\
(\mathrm{m})\end{array}$ \\
\hline 1 & 1087664.6 & 3687772.8 & 1.53 & 0.249 & 0.165 & 3.67 \\
\hline 2 & 1087663.2 & 3687778.6 & 1.59 & 0.186 & 0.102 & 2.28 \\
\hline 3 & 1087663.3 & 3687781.8 & 1.62 & 0.162 & 0.078 & 2.15 \\
\hline 4 & 1087666.6 & 3687787.5 & 1.55 & 0.226 & 0.142 & 1.04 \\
\hline 5 & 1087668.1 & 3687788.7 & 1.53 & 0.252 & 0.168 & 1.19 \\
\hline 6 & 1087670.7 & 3687792.4 & 1.52 & 0.257 & 0.173 & 4.89 \\
\hline 7 & 1087671.4 & 3687797.6 & 1.52 & 0.259 & 0.175 & 5.02 \\
\hline 8 & 1087671.8 & 3687803.6 & 1.58 & 0.204 & 0.120 & 3.76 \\
\hline 9 & 1087672.9 & 3687806.4 & 1.58 & 0.201 & 0.117 & 2.62 \\
\hline 10 & 1087674.6 & 3687810.7 & 1.56 & 0.219 & 0.135 & 4.51 \\
\hline 11 & 1087676.4 & 3687815.0 & 1.56 & 0.217 & 0.133 & 5.21 \\
\hline 12 & 1087676.9 & 3687817.4 & 1.50 & 0.277 & 0.193 & 5.18 \\
\hline 13 & 1087676.8 & 3687820.0 & 1.50 & 0.279 & 0.195 & 4.68 \\
\hline 14 & 1087677.1 & 3687822.4 & 1.53 & 0.250 & 0.166 & 4.51 \\
\hline \multirow{2}{*}{\multicolumn{4}{|c|}{$\begin{array}{l}\text { Avr. Difference } \\
\text { Std. Deviation }\end{array}$}} & 0.231 & 0.147 & 3.62 \\
\hline & & & & 0.035 & 0.035 & 1.49 \\
\hline
\end{tabular}

al., 2012; Wang et al., 2015). In an area like NASA Langley Research Center and Langley Air Force Base, where the terrain is converted lowlands and salt marshes, virtually no buffer exists between the valuable infrastructure and an impending storm surge intruding into the Back River estuary. 
Table 3. GPS-recorded wrack line data corresponding with Figure 8C.

\begin{tabular}{|c|c|c|c|c|c|c|}
\hline \# & $\begin{array}{l}\text { No rthing } \\
(\mathrm{m})\end{array}$ & $\begin{array}{l}\text { Eas ting } \\
\quad(\mathrm{m})\end{array}$ & $\begin{array}{c}\text { DEM } \\
\text { Height } \\
(\mathrm{m})\end{array}$ & $\begin{array}{l}\text { Difference } \\
\text { witho ut } \\
\text { Infiltration } \\
(\mathrm{m})\end{array}$ & $\begin{array}{l}\text { Diffe rence } \\
\text { with } \\
\text { Infiltration } \\
(\mathrm{m})\end{array}$ & $\begin{array}{l}\text { Ho rizontal } \\
\text { Dis tance } \\
\text { Diffe rence } \\
\text { (m) }\end{array}$ \\
\hline 1 & 1087565.3 & 3687330.9 & 1.52 & 0.265 & 0.201 & 2.21 \\
\hline 2 & 1087569.0 & 3687335.1 & 1.59 & 0.193 & 0.129 & 1.68 \\
\hline 3 & 1087570.1 & 3687340.3 & 1.63 & 0.159 & 0.095 & 1.92 \\
\hline 4 & 1087569.9 & 3687347.9 & 1.63 & 0.155 & 0.091 & 1.15 \\
\hline 5 & 1087569.8 & 3687354.1 & 1.65 & 0.132 & 0.068 & 1.04 \\
\hline 6 & 1087569.7 & 3687364.0 & 1.64 & 0.150 & 0.086 & 0.43 \\
\hline 7 & 1087570.5 & 3687390.8 & 1.67 & 0.120 & 0.056 & 0.28 \\
\hline \multirow{2}{*}{\multicolumn{4}{|c|}{$\begin{array}{l}\text { Avr. Difference } \\
\text { Std. Deviation }\end{array}$}} & 0.168 & 0.103 & 1.24 \\
\hline & & & & 0.049 & 0.049 & 0.73 \\
\hline
\end{tabular}

Hydrological fluid transport is a critical consideration when modeling relatively flat landscapes within the coastal plain such as the terrain characterizing the broader extent of the NASA Langley Research Center where the water table is regularly near to the exposed soil surface throughout the year. Calculating inundation thickness as the height of water above the topographic land surface is a useful method for evaluating the importance of coding precipitation into a hydrodynamic model as a model input. Figure 9A displays the maximum inundation thickness around NASA Langley Research Center and Langley Air Force Base after the Hurricane Isabel in a simulation neglecting precipitation. In contrast, Figure 9B illustrates the maximum inundation thickness in meters for Hurricane Isabel including precipitation input over the Back River peninsula.

Upon inclusion of precipitation data as an atmospheric model input, localized flooding non-contiguous to the storm surge flooding associated with Hurricane Isabel in the interior of NASA Langley Research Center is observed. Specific areas of localized precipitation-based flooding persist in the southwestern region of NASA Langley Research Center and the central to southwestern regions of Langley Air Force Base. Interior areas along the western edge of NASA Langley Research Center (which are not directly adjacent to the storm surge-induced flooding along the edge of the Back River estuary) are now shown to be inundated when precipitation is included. While some of these areas non-contiguous with the Back River estuary are local drainage infrastructure containing a water thickness of $25 \mathrm{~cm}$ or less, many areas in the southwestern portion of the map near Langley Air Force Base are inundated by precipitation-derived flooding between $1.00-1.75 \mathrm{~m}$. This is effectively exemplified in the difference map shown in Figure 9C. Figure 9C is the difference of Figure 9B minus Figure 9A, generated via GIS.

\section{Sea-Level Rise Scenarios}

Consideration of future sea-level rise and climate change is critically important for coastal regions (Boon, 2004). To address these rising concerns, a series of sea-level rise scenarios using the developed model grid with 5-m sub-grid during Hurricane Isabel as a base case at $+0 \mathrm{~cm},+37.5 \mathrm{~cm},+75 \mathrm{~cm}$, and $+150 \mathrm{~cm}$ have been devised to utilize the greatest storm surge height observed in the last several decades at NASA Langley Research Center. Inundation peaks during Hurricane Isabel for the sealevel rise cases were the original storm at $1.902 \mathrm{~m}$, Isabel +37.5 $\mathrm{cm}$ at $2.285 \mathrm{~m}$, Isabel $+75 \mathrm{~cm}$ at $2.696 \mathrm{~m}$, and Isabel $+150 \mathrm{~cm}$ at a maximum inundation height of $3.460 \mathrm{~m}$. Spatial comparison
Table 4. Modeled water level elevation errors for Sites $A-C$ featured in Figure 8 presented as Average Local DEM Height ( $m$ ) divided by the Average Modeled Water Elevation (m) x 100 then subtracted by 100 to represent the ratio of model overprediction; negative values reflect model underprediction.

\begin{tabular}{lccc}
\hline \hline Scenario & Average Local & Average Modeled & \multirow{2}{*}{ \% Overprediction } \\
& DEM Height (m) & Water Elevation (m) & \\
Site A without Infiltration & 1.67 & 1.8 & 7.59 \\
Site B without Infiltration & 1.55 & 1.78 & 15 \\
Site C without Infiltration & 1.62 & 1.8 & 11.21 \\
Average & 1.61 & 1.79 & 11.17 \\
Std. Deviation & 0.06 & 0.01 & - \\
& & & \\
Site A with Infiltration & 1.67 & 1.65 & -1.48 \\
Site B with Infiltration & 1.55 & 1.63 & 5.31 \\
Site C with Infiltration & 1.62 & 1.65 & 1.94 \\
Average & 1.61 & 1.64 & 1.83 \\
Std. Deviation & 0.06 & 0.01 & - \\
\hline
\end{tabular}

maps of four Hurricane Isabel sea-level rise climate change scenarios are shown in Figure 10 A-D. The maximum inundation thickness is shown in the maps focused on the central region of NASA Langley Research Center as it backs up to Tabb Creek, a tidal tributary that feeds into the Back River estuary. Linear flood distances were calculated using the maximum inundation extents from the edge of Tabb Creek to NASA building 1251 (one of the few buildings above water in Figure 10D). An average linear flood distance of $125 \mathrm{~m}$ was observed in 2003 during Hurricane Isabel, which translated to estimated linear flood extents of $515 \mathrm{~m}, 810 \mathrm{~m}$, and $2,550 \mathrm{~m}$, given +37.5 $\mathrm{cm},+75 \mathrm{~cm}$, and $+150 \mathrm{~cm}$ increases in mean sea level, respectively.

In the climate change scenarios, only storm surge flooding associated with sea-level rise was utilized with no precipitation input, as it is impossible to accurately anticipate what the future precipitation rates would be with a future storm system of the magnitude of Hurricane Isabel (Figure 10A) at Isabel $+37.5 \mathrm{~cm}$ (Figure 10B), Isabel $+75 \mathrm{~cm}$ (Figure 10C), and Isabel $+150 \mathrm{~cm}$ (Figure 10D). The goal of this simulated series of sea-level rise scenarios is to assess the inundation threat posed by future sealevel rise associated with climate change, and neglecting precipitation allows the maximum inundation maps to more clearly reflect the storm surge-induced flooding associated with increasing sea level. According to the most recent IPCC projections for future sea-level rise scenarios, a global increase in mean sea level of $26-82 \mathrm{~cm}$ is possible by the year 2100 (Church et al., 2013), which translates the simulated cases for a storm similar to Hurricane Isabel to the flooding extents depicted in Figure 10B by the year 2054, 9C by the year 2094, and $9 \mathrm{D}$ in the year 2175, assuming the upper bound of their estimate. In these sea-level rise scenarios, it is critical to recognize that the predicted peak inundation levels are higher than simply the sum of the storm surge at the present mean sea level plus the projected sea-level rise value projected by the 

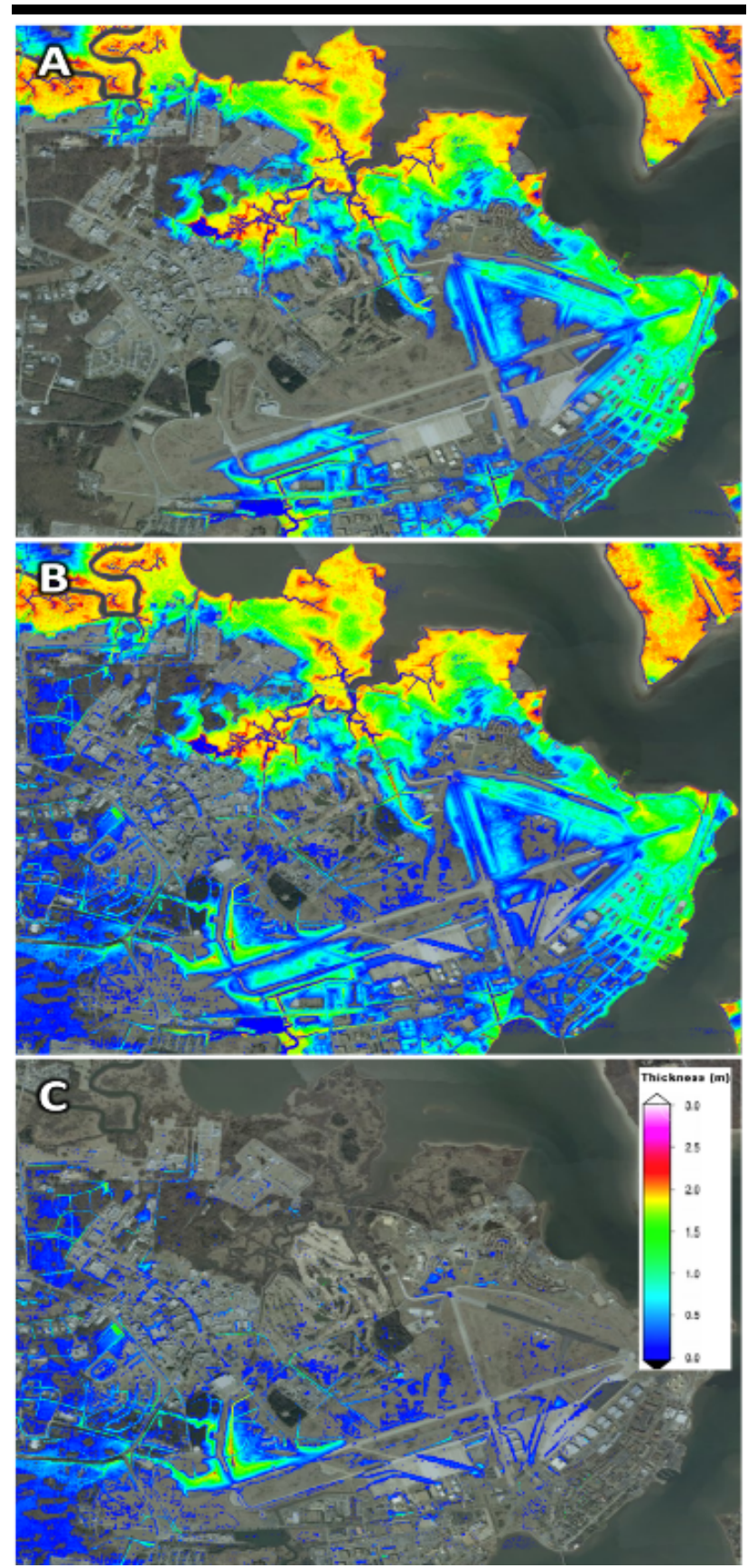

Figure 9. Inundation thickness map for Hurricane Isabel showing the effects of (A) only storm surge, (B) the effects of storm surge coupled with precipitation, and $(\mathrm{C})$ a difference map to illustrate the flooding impact of precipitation at NASA Langley Research Center.
IPCC, which signifies a nonlinear relationship between sea-level rise and peak storm surge height. This non-linearity could make a compelling case for the use of hydrodynamic models over bathtub models to investigate sea-level rise scenarios (Schmid, Hadley, and Waters, 2014). These IPCC estimations of sea-level rise do not include accelerated contributions from the melting of large ice sheets and that the actual sea-level rise realized in the study area could be significantly larger than these projections.

\section{CONCLUSIONS}

Airborne lidar data acquired by NASA in 2005 were incorporated into an existing 5-m resolution topobathymetric DEM to efficiently and accurately resolve fine scale hydrologic features including narrow drainage ditches and trenches within NASA Langley Research Center. A 10-m buffer was used to minimize conflicting overlap to ensure a seamless cross-shore transition between disparate multi-temporal sources of topography and bathymetry measurements, while still preserving precise representation near shore drainage features. The preservation of the shoreline elevations, creeks, and drainage ditches is vital for the mapping of fluid flux through each grid cell side of the sub-grid model, which ultimately regulates the water depth and extent of inundation via distribution of water volume within each model grid cell. Two ideal test cases were conducted under heavy precipitation conditions with detailed topographic features resolved. The sub-grid hydrological transport model simulated channeling of rainfall in an unobstructed ditch, and expansion of lateral inundation in a blocked drainage basin. This established that the sub-grid model can be used as a hydrological transport model to replicate inundation for storm surge applications.

Two storm surge scenarios were tested using the sub-grid hydrological transport model approach. First, time series comparisons for Hurricane Irene (2011) satisfactorily compared with the NASA Tide01 gauge and achieved a correlation coefficient of $\mathrm{R}^{2}=0.97$ and an RMSE of $0.079 \mathrm{~m}$. The NASAinstalled tide gauge was important for benchmarking both for tidal forcing and for monitoring storm-induced water level variations at NASA Langley Research Center. A suite of NASAcollected GPS wrack line observation data at separate sites was used in a comprehensive inundation comparison between subgrid model results and observed locations of collected debris immediately after the storm. NASA-collected GPS wrack line observation data were particularly useful for evaluating modeled inundation extent. The GPS wrack line data were utilized in a rigorous comparison by calculating the difference between observed and model-predicted maximum inundation. When soil infiltration was not considered, the mean difference in maximum water elevations between the model and observation was approximately $10 \%$. The absolute difference reduced to $2-5 \%$ when spatially-varying infiltration was considered. The corresponding distance comparison between the modeled extents and the observed maximum horizontal extent of inundation was within $1-8.5 \mathrm{~m}$. 

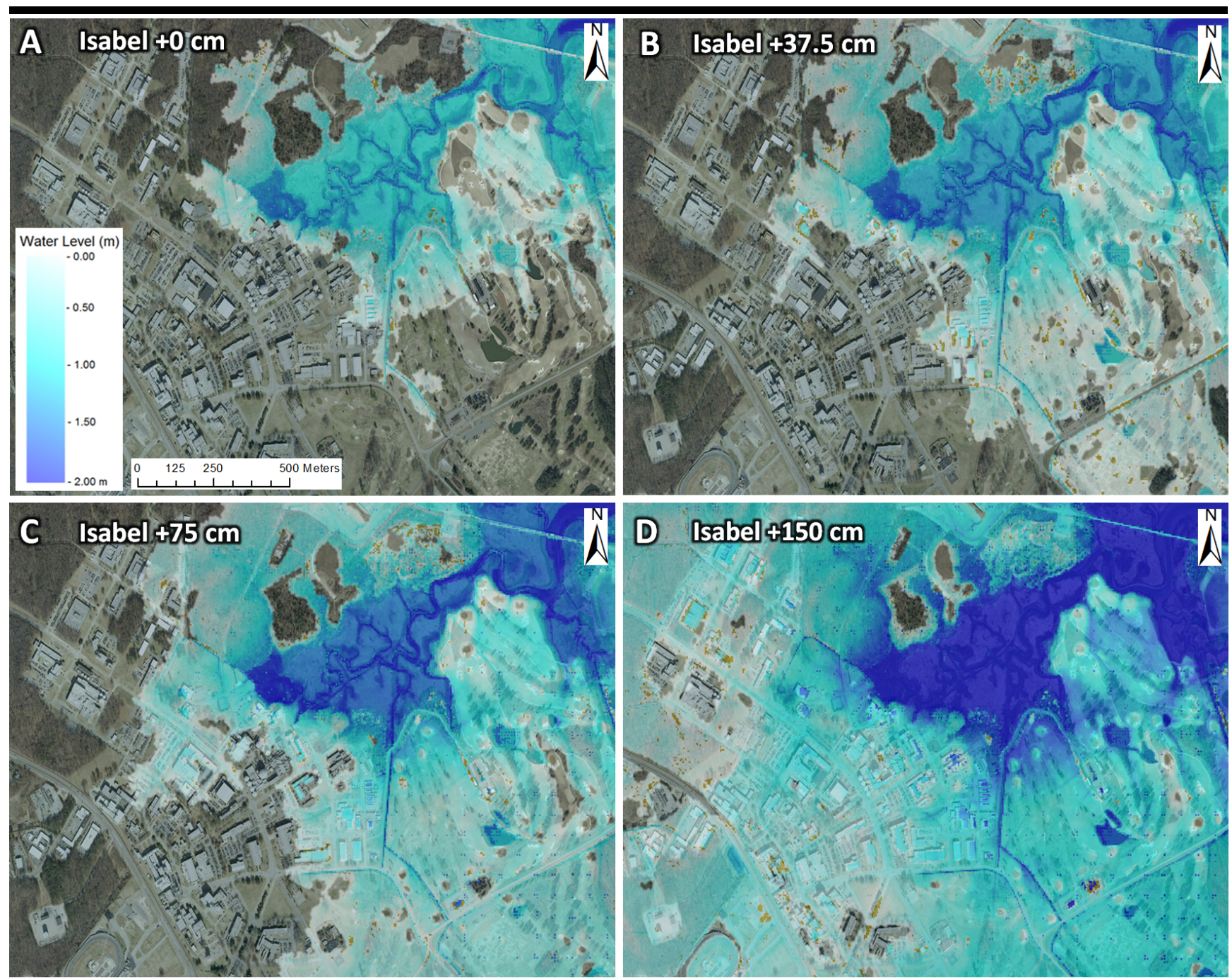

Figure 10. Impact of Hurricane Isabel in the central region of NASA Langley Research Center in four sea-level rise scenarios including the original storm: (A) $+0 \mathrm{~cm},(B)+37.5 \mathrm{~cm},(\mathrm{C})+0.75 \mathrm{~cm}$, and (D) $+150 \mathrm{~cm}$. These inundation maps do not account for elevation uncertainty.

As a sensitivity test, Hurricane Isabel (2003) model results were used to compare the impact of modeling storm surge with and without precipitation input. It was found that a region in the southwest of NASA Langley Research Center was particularly prone to precipitation-induced flooding, which was not directly related to the storm surge. Additionally, a series of simulations accounting for future sea-level rise associated with climate change prediction scenarios specified by the IPCC were addressed using the case study of Hurricane Isabel, the most devastating storm system to impact the Greater Hampton Roads region in recent history. It was estimated that the maximum horizontal extent of inundation will be expanded inland by 0.5 $\mathrm{km}, 0.8 \mathrm{~km}$, and $2.5 \mathrm{~km}$ with increases of mean sea level of $+37.5 \mathrm{~cm},+75 \mathrm{~cm}$, and $+150 \mathrm{~cm}$, respectively. Ultimately, the utility of incorporating high-resolution lidar-derived measurements into a topobathymetric DEM was effectively demonstrated using a hydrodynamic sub-grid model coupled with time-varying precipitation inputs to efficiently resolve the important fine-scale drainage infrastructure necessary to address inundation within the context of a hydrological transport model in the Virginia coastal plain.

\section{ACKNOWLEDGMENTS}

The authors would like to acknowledge the VIMS TideWatch database for useful water level predictions and observations used for model calibrations, and open boundary forcing near the mouth of the Back River estuary. The NASA Capable (CAPABLE.larc.nasa.gov), data repository provided useful water level and meteorological observations for use in flooding simulations. 


\section{LITERATURE CITED}

American Society of Civil Engineers and the Water Pollution Control Federation, 1986. Design and Construction of Sanitary and Storm Sewers. ASCE Manuals and Reports of Engineering Practice No. 37, WPCF Manual of Practice No. 9, American Society of Civil Engineers, New York, NY, and Water Pollution Control Federation, Washington, D.C.

Boon, J., 2004. The three faces of Isabel; Storm surge, storm tide, and sea level rise. http://web.vims.edu/physical /research/isabel/?svr=www.

Boon, J., 2008. Virginia Institute of Marine Science: VIMS Tidewatch. http://www.vims.edu/bayinfo/tidewatch/ index.php.

Burghardt, W., 1994. Soils in urban and industrial environments. Journal of Plant Nutrition and Soil Science, 157, 205-214.

Carpenter, T.M. and Georgakakos, K.P., 2004. Impacts of parametric and radar rainfall uncertainty on the ensemble streamflow simulation of a distributed hydrologic model. Journal of Hydrology, 298, 202-221.

Casulli, V., 2009. A high-resolution wetting and drying algorithm for free-surface hydrodynamics. Intl. Journal for Numerical Methods in Fluid Dynamics, 60, 391-408.

Casulli, V. and Stelling, G. 2011. Semi-implicit sub-grid modeling of three-dimensional free-surface flows. Intl. Journal for Numerical Methods in Fluid Dynamics, 67, 441449

Casulli, V. and Zanolli, P., 1998. A three-dimensional semiimplicit algorithm for environmental flows on unstructured grids, Proc. of Conf. on Num. Methods for Fluid Dynamics, 57-70.

Casulli, V. and Zanolli, P., 2012. Iterative solutions of mildly nonlinear systems. Journal of Computational and Applied Mathematics, 236(16), 3937-3947.

Cho, K.-H.; Wang, H.V.; Shen, J.; Valle-Levinson, A., and Teng, Y-C., 2012. A modeling study on the response of Chesapeake Bay to hurricane events of Floyd and Isabel. Ocean Modelling, 49(50), 22-46.

Church, J.A.; Clark, P.U.; Cazenave, A.; Gregory, J.M.; Jevrejeva, S.; Levermann, A.; Merrifield, M.A.; Milne, G.A.; Nerem, R.S.; Nunn, P.D.; Payne, A.J.; Pfeffer, W.T.; Stammer D., and Unnikrishnan, A.S., 2013. Sea Level Change. In: Stocker, T.F.; Qin, D.; Plattner, G.-K.; Tignor, M.; Allen, S.K.; Boschung, J.; Nauels, A.; Xia, Y.; Bex, V., and Midgley, P.M. (eds.), Climate Change 2013: The Physical Science Basis. Contribution of Working Group I to the Fifth Assessment Report of the Intergovernmental Panel on Climate Change. Cambridge, United Kingdom: Cambridge University Press, pp. 1137-1216.

ESRI, 2011. ArcGIS Desktop: Release 10. Redlands, CA: Environmental Systems Research Institute.

Fetter, C.W., 1994. Applied Hydrogeology, 3rd Edition. New Jersey: Prentice Hall, Inc., 61-196.

Fry, J.; Xian, G.; Jin, S.; Dewitz, J.; Homer, C.; Yang, L.; Barnes, C.; Herold, N., and Wickham, J., 2011. Completion of the 2006 National Land Cover Database for the Conterminous United States, $P E \& R S, 77(9), 858-864$.

Gong, W.; Shen, J., and Reay, W.G., 2007. The hydrodynamic response of the York River estuary to Tropical Cyclone Isabel, 2003. Estuarine, Coastal and Shelf Science, 73, 695-
710.

Gong, W.; Shen, J.; Cho, K.H., and Wang, H., 2009. A numerical model study of barotropic subtidal water exchange between estuary and subestuaries tributaries in the Chesapeake Bay during northeaster events. Ocean Modelling, 263-4, 170-189.

Huising, E.J. and Gomes Pereira, L.M., 1998. Errors and accuracy estimates of laser data acquired by various laser scanning systems for topographic applications. ISPRS Journal of Photogrammetry \& Remote Sensing, 53, 245-261.

Hwang, Y.; Clark, M.; Rajagopalan, B., and Leavesley, G., 2012. Spatial interpolation schemes of daily precipitation for hydrologic modeling. Stochastic Environmental Research and Risk Assessment, 26(2), 295-320.

Isenburg, Martin, 2012. LAStools - efficient tools for Lidar processing. V.111216. http://lastools.org.

Kleinosky, L.R.; Yarnal, B., and Fisher, A., 2007. Vulnerability of Hampton Roads, Virginia to storm-surge flooding and sealevel rise. Natural Hazards, 40, 43-70.

Lippert, C., 2010. Smile: Consult; First Experiences with SubGrid Generation for UnTRIM2. The 7th Annual UnTRIM Workshop (Trento, Italy), 56p.

Loftis, J., 2012. Simulation of coastal inundation instigated via storm surge, river discharge, and precipitation in the Chesapeake Bay using sub-grid modeling with lidar-derived digital elevation models. Oceans, 1-33.

Loftis, J.D., 2014. Development of a Large-Scale Storm Surge and High-Resolution Sub-Grid Inundation Model for Coastal Flooding Applications: A Case Study during Hurricane Sandy. Gloucester Point, Virginia: Virginia Institute of Marine Science, College of William and Mary, Ph.D. dissertation, 226p.

Loftis, J.D.; Wang, H., and DeYoung, R., 2013. Storm Surge and Inundation Modeling in the Back River Watershed for NASA Langley Research Center. NASA Technical Report: NASA/TM-2013-218046, 62p.

Loftis, J.D.; Wang, H.V.; Hamilton, S.E.; and Forrest, D.R., 2015. Combination of Lidar Elevations, Bathymetric Data, and Urban Infrastructure in a Sub-Grid Model for Better Predicting Inundation in New York City during Hurricane Sandy. arXiv preprint arXiv:1412.0966.

Mark, O.; Weesakul, S.; Apirumanekul, C.; Aroonnet, S-B, and Djordjevic, S., 2004. Potential and limitations of 1D modelling of urban flooding. Journal of Hydrology, 299(3), 284-299.

Meehl, G.A.; Stocker, T.F.; Collins, W.D.; Friedlingstein, P.; Gaye, A.T.; Gregory, J.M.; Kitoh, A.; Knutti, R.; Murphy, J.M.; Noda, A.; Raper, S.C.B.; Watterson, I.G.; Weaver, A.J., and Zhao, Z.-C., 2007. Global climate projections. In: Solomon, S.; Qin, D.; Manning, M.; Chen, Z.; Marquis, M.; Averyt, K.B.; Tignor, M., and Miller, H.L. (eds.), Climate Change 2007: The Physical Science Basis. Contribution of Working Group I to the Fourth Assessment Report of the Intergovernmental Panel on Climate Change. Cambridge, United Kingdom: Cambridge University Press, pp. 747-845.

NASA Langley GIS Team, 2010. LaRC Prototype Tide Measurement Station. Langley Research Center, Hampton, VA. http:/capable.larc.nasa.gov/tide-gauge/docs-pdf/ Langley sea level gauge report.pdf. 
NASA Langley GIS Team, 2011. NASA Langley Research Center Geographic Information Systems (GIS) Team. http://gis.larc.nasa.gov/.

NASA Langley GIS Team, 2012. LaRC Tide Measurement Stations. Langley Research Center, Hampton, VA. http://capable.larc.nasa.gov/tide-gauge/docs-pdf/New stations_report.pdf.

NOAA NCDC, 2003. NOAA National Climatic Data Center: Climate Data Online. http://www.ncdc.noaa.gov/cdoweb/search?datasetid=PRECIP HLY\#.

NOAA NCDC, 2011. NOAA National Climatic Data Center: Climate Data Online. http://www.ncdc.noaa.gov/cdo-web/.

NOAA NGDC, 2011. NOAA National Geophysical Data Center: Bathymetric Data Viewer. https://www.ngdc. noaa.gov/mgg/bathymetry/hydro.html.

NOAA Tides and Currents, 2011. Water Levels - Station Selection. http://tidesandcurrents.noaa.gov/stations.html ?type $=$ Water + Levels.

Parker, B.; Hess, K.W.; Milbert, D.G., and Gill, S., 2003. A national vertical datum transformation tool. Sea Technology, 44(9), 10-15.

Post; Buckley; Schuh, and Jernigan, 2005. Hurricane Isabel Assessment, a Review of Hurricane Evacuation Study Products and Other Aspects of the National Hurricane Mitigation and Preparedness Program NHMPP in the Context of the Hurricane Isabel Response. NOAA. http://www.csc.noaa.gov/hes/docs/postStorm

/Isabel_PostStorm_Summary.pdf.

Schmid, K.; Hadley, B., and Waters, K., 2014. Mapping and portraying inundation uncertainty of bathtub-type models. Journal of Coastal Research, 30(3), 548-561.

Shen, J.; Wang, H.V.; Sisson, M., and Gong W., 2006. Storm tide simulation in the Chesapeake Bay using an unstructured grid model. Estuarine, Coastal and Shelf Science, 68, 1-16.

Shen, J. and Gong, W., 2009. Influence of model domain size, wind direction and Ekman transport in storm surge development inside the Chesapeake Bay: A case study of extratropical cyclone Ernesto, 2006. Journal of Marine Systems, 75, 198-215.

Stamey, B.; Smith, W.; Carey, K.; Garbin, D.; Klein, F.; Wang, H.; Shen, J.; Gong, W.; Cho, J.; Forrest, D.; Friedrichs, C.; Boicourt, W.; Li, M.; Koterba, M.; King, D.; Titlow, J.; Smith, E.; Siebers, A.; Billet, J.; Lee, J.; Manning, D.; Szatkowski, G.; Wilson, D.; Ahnert, P., and Ostrowski, J., 2007. Chesapeake Inundation Prediction System: A Regional
Prototype for a National Problem. Final report submitted to NOAA IOOS Program Office. http://www.dtic.mil/dtic/tr/fulltext/u2/a518173.pdf.

Stelling, G. and Kerncamp, H., 2010. Personal Communication. Sweet, W.; Park, J.; Marra, J.; Zervas, C., and Gill, S., 2014. Sea Level Rise and Nuisance Flood Frequency Changes around the United States. NOAA Technical Report NOS CO-OPS $073 . \quad \mathrm{http}: / /$ tidesandcurrents.noaa.gov/publications NOAA_Technical_Report_NOS_COOPS_073.pdf.

Taylor, L.A.; Eakins, B.W.; Carignan, K.S.; Warnken, R.R.; Sazonova, T.; Schoolcraft, D.C., and Sharman, G.F., 2008. Digital Elevation Model of Virginia Beach, Virginia: Procedures, Data Sources and Analysis, Boulder, Colorado: National Geophysical Data Center, NOAA Technical Memorandum NESDIS NGDC-7, 34p.

Virginia Center for Coastal Resources Management, 2013. VA Shoreline Inventories. http://ccrm.vims.edu/gis_data_maps/ shoreline_inventories/Virginia_ShorelineInventory_2013.zip.

Virginia Institute of Marine Science, 2013. Recurrent Flooding Study for Tidewater Virginia, Report submitted to the Virginia General Assembly, January 2013. http://ccrm.vims.edu/recurrent_flooding/Recurrent_Flooding Study_web.pdf.

Wang, H.V; Cho, K.; Shen, J., and Wang, Y., 2005. What has been learned about storm surge dynamics from Hurricane Isabel model simulations? Hurricane Isabel in Perspective Conference (Baltimore, Maryland), pp. 117-125.

Wang, H.V.; Loftis, J.D.; Liu, Z.; Forrest, D., and Zhang, J., 2014. The storm surge and sub-grid inundation modeling in New York City during Hurricane Sandy. Journal of Marine Science and Engineering, 2(1), 226-246.

Wang, H.V.; Loftis, J.D.; Forrest, D.; Smith, W., and Stamey, B., 2015. Modeling storm surge and inundation in Washington, DC, during Hurricane Isabel and the 1936 Potomac River Great Flood. Journal of Marine Science and Engineering, 3(3), 607-629.

Webster, T.L. and Dias, G., 2006. An automated GIS procedure for comparing GPS and proximal LIDAR elevations. Computers and Geosciences, 32(6), 713-726.

Yang, Z.; Myers, E.; Wong, A., and White, S., 2008. VDatum for Chesapeake Bay, Delaware Bay and adjacent coastal water areas: Tidal datums and sea surface topography. Silver Spring, Maryland: NOAA Technical Memorandum NOS CS15, 110p. 


\section{APPENDIX}

Rainfall reaching the land surface can infiltrate into pervious soil. Soil has a finite capacity to absorb water. Conditions that favor a high infiltration rate include coarse soils, well-vegetated land, and land use practices that avoid soil compaction; in contrast, the more urbanized the land use, the greater the percentage of the impervious surfaces and the less the percentage of infiltration (Burghardt, 1994; Mark et al., 2004).

The rational equation (Fetter, 1994) was used to describe the rainfall-runoff relationship. Values of $C$ from Equation 2 are given in Table A for a variety of different land uses to account for differing rates of infiltration (American Society of Civil Engineers and the Water Pollution Control Federation, 1986). Based on the NLCD 2006 (Fry et al., 2011) land use of NASA Langley Research Center as shown in Figure A, the infiltration rate (1) for Hurricane Irene was estimated and shown in Figure 6.

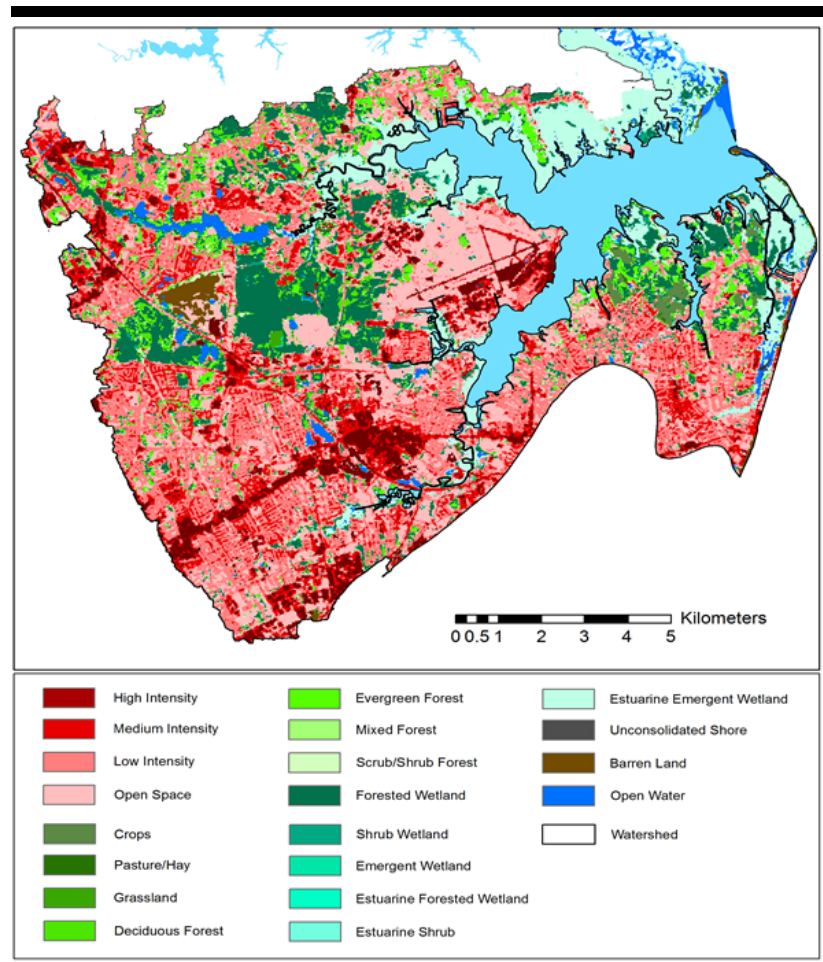

Figure A. Land use map for the Back River watershed with developed lands shown in red hues and vegetated land displayed with green hues via the 2006 National Land Cover Database (Fry et al., 2011).
Table A. Runoff Factor for Rational C Equation.

\begin{tabular}{|c|c|}
\hline Description of Area & $\mathrm{C}$ \\
\hline \multicolumn{2}{|l|}{ Business } \\
\hline Downtown & $0.70-0.95$ \\
\hline Neighborhood & $0.50-0.70$ \\
\hline \multicolumn{2}{|l|}{ Residential } \\
\hline Single Family & $0.30-0.50$ \\
\hline Multi-units, Detached & $0.40-0.60$ \\
\hline Multi-units, Attached & $0.60-0.75$ \\
\hline Residential Suburban & $0.25-0.40$ \\
\hline Apartment & $0.50-0.70$ \\
\hline \multicolumn{2}{|l|}{ Industrial } \\
\hline Light & $0.50-0.80$ \\
\hline Heavy & $0.60-0.90$ \\
\hline Parks, Cemeteries & $0.10-0.25$ \\
\hline Playgrounds & $0.20-0.35$ \\
\hline Railroad Yard & $0.20-0.35$ \\
\hline Unimproved & $0.10-0.30$ \\
\hline \multicolumn{2}{|l|}{ Character of Surface } \\
\hline \multicolumn{2}{|l|}{ Pavement } \\
\hline Asphalt or Concrete & $0.70-0.95$ \\
\hline Brick & $0.70-0.85$ \\
\hline Roofs & $0.75-0.95$ \\
\hline \multicolumn{2}{|l|}{ Lawns, Sandy Soil } \\
\hline Flat, up to $2 \%$ Grade & $0.05-0.10$ \\
\hline Average, $2 \%-7 \%$ Grade & $0.10-0.15$ \\
\hline Steep, over 7\% Grade & $0.15-0.20$ \\
\hline \multicolumn{2}{|l|}{ Lawns, Heavy Soil } \\
\hline Flat, up to $2 \%$ Grade & $0.13-0.17$ \\
\hline Average, $2 \%-7 \%$ Grade & $0.18-0.22$ \\
\hline Steep, over 7\% Grade & $0.25-0.35$ \\
\hline
\end{tabular}

